\title{
Palaeoceanographic and climatic implications of a new Mediterranean Outflow branch in the southern Gulf of Cadiz
}

3

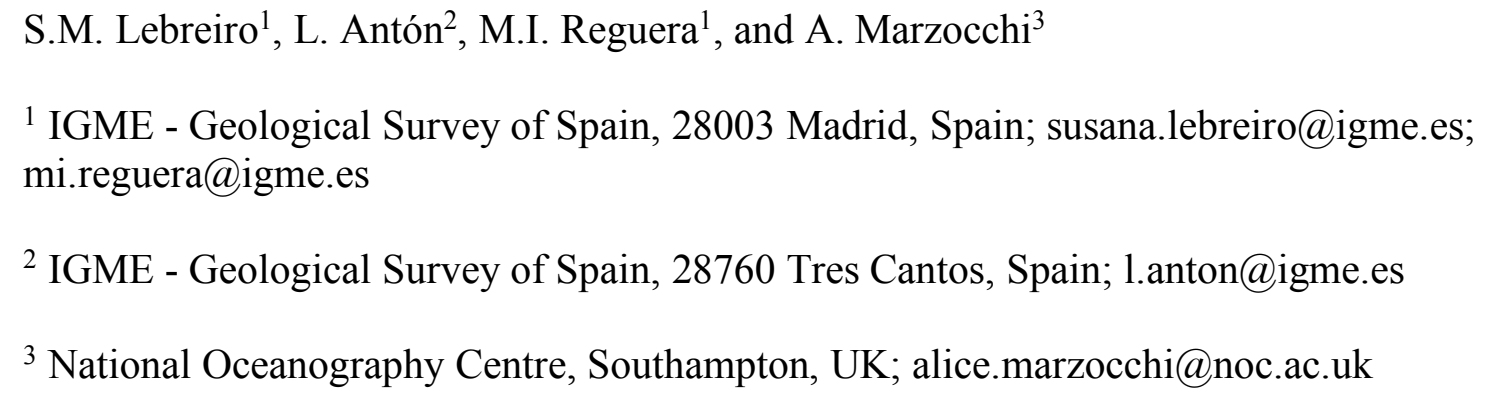

Key words: Quaternary; Paleoceanography; climate modeling; North Atlantic; Foraminifers; stable isotopes; sortable silt; Mediterranean Outflow; Morocco contourite drift

\begin{abstract}
The presence of contourite drifts in the southern Gulf of Cadiz (GoC) along the Moroccan margin raises questions about the (re)circulation of Mediterranean Outflow Water (MOW) in the GoC and the origin of the currents depositing them. Here, we compare two cores representative of Iberian and Moroccan contourite drifts, covering the last $22 \mathrm{kyr}$. Although the whole sequence is contouritic in character, it reflects the interaction of distinctive silty-contourite facies (high flow velocity periods) imbedded in muddy-contourite facies (low flow velocity periods). Evidence from benthic foraminifera $\delta^{13} \mathrm{C}$, sortable silt grain-size, oceanographic CTD profiles and numerical simulations, indicate the Mediterranean water mass as the source of the southern contourite deposits. Our data, therefore, suggests an additional branch of upper-MOW veering southwards off the Straits of Gibraltar along the Moroccan margin. During MIS-(Marine Isotope Stage) 2, upper-MOW was a sluggish current while in the Holocene upper-MOW dominated as a fast, semi-steady flow. Throughout the deglaciation, silty contourites associated with higher flow speeds were deposited in the northern and southern GoC during cold events such as Heinrich Stadial 1 (HS1) and the Younger Dryas, forced by global millennial-scale climate variability. Millennial variability also appears to drive the deposition of silty-contourites in the Holocene. We estimated an average duration of $1 \mathrm{ka}$ for the process of depositing a fast contourite unit. The case of silty-contourite I6 (within HS1) allows us to illustrate with extremely high resolution a "rapid" sequential change in circulation, with gradual slow-down of dense Mediterranean water while surface was freshening (HS1), provoking injection of highsalinity intermediate waters (via contour-currents) into the GoC, and hence the North Atlantic. The subsequent brief collapse of dense water formation in the Mediterranean Sea triggered a major increase in sea surface temperatures $\left(10^{\circ} \mathrm{C} / \mathrm{ka}\right)$ in the $\mathrm{GoC}$, developing into the next interstadial (Bølling/Allerød). The impact of Mediterranean intermediate waters is manifested here by triggering a substantial rearrangement of intermediate and deep circulation in the North Atlantic, which would have further impacted the Atlantic Meridional Overturning Circulation (AMOC).
\end{abstract}

\section{INTRODUCTION}


The Mediterranean Outflow Water (MOW), a water mass flowing mainly at intermediate depths in the eastern North Atlantic, plays an important role in the development of Contourite Depositional Systems west of the Gibraltar gateway. Its interaction with the adjacent continental margins determines the evolution of local contourite drifts in the northern side of the Gulf of Cadiz $(\mathrm{GoC})$. While the MOW is considered a well-established source for the Faro Drift contourites deposited on the Iberian margin (Faugères et al., 1984; Gonthier et al. 1984; review in Hernández-Molina et al., 2006; Llave et al., 2001; Nelson et al., 1993; Rogerson et al., 2006; Sierro et al., 1999; Stow, 1985), the nature of the current which is depositing the Moroccan Drift contourites (Suppl. Fig. S1) is poorly understood.

We envisage three possible hypotheses for the occurrence of contourites along the Moroccan margin, at an equivalent depth $(550 \mathrm{~m})$ as those found on the Iberian margin (Fig. 1A). First, the upper-MOW splits off Gibraltar and circulates not only along the Iberian margin, but also in a southward branch along the Moroccan margin (Fig. 2). Second, the northern lower-MOW jet turns southwards at Cape St. Vincent, and reenters the GoC mixed with North Atlantic Central Water (NACW) and modifiedAntarctic Intermediate Water (AAIW), in the form of meddies (Mediterranean eddies) as infered in Ámbar et al. (2008), Carton et al. (2002), Iorga and Lozier (1999), and Quentel et al. (2011) (Fig. 2). Or third, modified-AAIW flows directly from the South Atlantic along the NW African margin to the southern margin of the GoC, before mixing with MOW (Fig. 2).

The verification of hypothesis 1 would imply an underestimation of the influence of MOW on the Atlantic Thermohaline Circulation (Rogerson et al., 2006; Voelker et al., 2006). A number of CTD (Conductivity-Temperature-Depth, BODC-British data, Fig. $1 \mathrm{~B}, \mathrm{C})$ profiles gathered in oceanographic cruises along the Moroccan margin within the $\mathrm{GoC}$, shows evidence for the presence of modern MOW in the area at a depth of 700$1400 \mathrm{~m}$, as well as further south in the passage between Morocco and the Canary Islands at $29^{\circ} \mathrm{N}$ latitude (Hernández-Guerra et al., 2003; Knoll et al., 2002; Llinás et al., 2002; Machín et al., 2010; 2016), and offshore the Canary Islands (Armi et al., 1989; Richardson et al., 2000; Verdiere, 1992). Zahn et al. (1987), focussing on C and O isotopes, also inferred that the MOW path bathed the NW African margin down to Cape Blanc $\left(21^{\circ} \mathrm{N}\right.$ latitude) in the past $27 \mathrm{kyr}$, but shoaled to less than $1000 \mathrm{~m}$ between $10-14$ kyr. Hypothesis 2 would require buoyancy of the lower-MOW and an increased flow velocity, independently of the water mixing, when the current re-enters the $\mathrm{GoC}$ and approaches the Moroccan margin. This would imply unconvincing hydro-dynamics, involving meddies converted into strong and/or semi-permanent and confined contourcurrents. Concerning hypothesis 3 , modified-AAIW has been documented at midlatitudes in the North Atlantic (Álvarez et al., 2004), and therefore its presence in the GoC is not unexpected (Cabeçadas et al., 2002; Louarn and Morin, 2011). Vandorpe et al. (2014) and Van Rooij et al. (2011) have also suggested the presence of modifiedAAIW in palaeo-records. The current could have enough energy, or eventually gain velocity interacting with the sea floor, to build a contourite drift. This current could ultimately join the upper-MOW along Faro Drift, under the effect of Coriolis force, veering its route $\mathrm{N}$ in the GoC (Louarn and Morin, 2011).

Seismic profiles have shown developed contourite drifts on the Moroccan margin at an equivalent water depth of the upper-MOW along the Iberian margin (Casas et al., 2010; Vancraeynest, 2015; Van den Berghe, 2015; Vandorpe et al., 2014; Van Rooij et al., 2011; Van Tornhout, 2017) (Suppl. Fig. S1). In the centre of the GoC, off the well- 
known MOW northern Iberian path, very thin contourites have been identified at the latitude of the Gibraltar gateway but deeper (Voelker et al., 2006; core MD99-2339). On the other hand, cores barren of contourite facies coarser then mud have also been reported in the $\mathrm{GoC}$ (Penaud et al., 2011; MD04-2805 CQ, 34.52 $\mathrm{N}, 7.02^{\circ} \mathrm{W}, 859 \mathrm{~m}$ ). In these cores, a clear continuous pattern of typical North Atlantic global climatic events (Heinrich Stadial events, Greenland inter/stadials, Younger Dryas, Bølling/Allerød) is extracted from the facies. The contouritic character of the whole sequence of a drift is highly variable in the sedimentological context of the GoC. The robustness of the reference model of Gonthier et al. (1984) characterized by short-lived currents has been recently questioned, proposing contour-currents as long-term stable regimes (Rebesco and Carmengheri, 2008; Rebesco et al., 2014). Quantifying the duration of deposition events is crucial to propose new paradigms.

In this paper we assume the current concept of a contourite considered as the "product of sediments deposited or substantially reworked by the persistent action of bottom currents near the seafloor" (Stow et al., 2002). It is pointed out in the literature that contourites may occur interbedded with other sediment types, and that interaction of processes is the norm rather than the exception (Rebesco et al., 2014). These authors also state that we are far from having defined a set of universal diagnostic criteria for contourites and their processes of formation. Our work aims to progress the understanding of these processes.

Here, our approach consists of firstly comparing two series of contouritic records throughout the last $22 \mathrm{kyr}$ in the $\mathrm{GoC}$ from two sites at a water depth of $550 \mathrm{~m}$, bathed by the upper-MOW: GC-01A in the Faro Drift of the Iberian margin and MVSEIS_TG-2 in the Moroccan Drift of the African margin (Fig. 1). From a multi-proxy detailed analysis of planktonic and benthic stable isotopes, sortable silt mean speed and climatic conditions from planktonic foraminifera assemblages, we tracked the different water masses (MOW, Atlantic entrained MOW, or Southern Ocean-sourced intermediate water) flowing on either sides of the GoC. Secondly, we compared the climate coherency at times of intensification of contour-currents depositing contourites in the northern and southern sites. And finally, the duration of contourite deposition was estimated, supported by a consistent chronostratigraphy.

\section{AREA OF STUDY}

\subsection{Oceanographic setting}

The $\mathrm{GoC}$ (limited west by the $9^{\circ} \mathrm{W}$ meridian) plays an important role as a mid-latitude marginal basin where mesoscale horizontal and vertical mixing characterises the exchange between Mediterranean and North Eastern Atlantic Ocean water masses (Arhan and King, 1995; Kinder and Parrilla, 1987; Millot, 1999; Millot, 2009; Rogerson et al., 2012; Serra et al., 2010).

The surface is occupied by Eastern North Atlantic Central Water (ENACW) with a clear seasonal thermocline at the very near-surface $\left(23^{\circ} \mathrm{C} ; 36.5\right.$ salinity), reduced down to 550 $\mathrm{m}$, and minimum salinity of 35.5 (Jenkins et al., 2015; Machín et al., 2006). The NACW re-circulates as a $300 \mathrm{~km}$-wide year-long southward flow in the Moroccan margin (up to $33^{\circ} \mathrm{N}$ latitude, cape Beddouza) (Machín et al., 2006). 
At intermediate depths, modified Antarctic Intermediate Water (AAIW) enters the GoC from the south, through the corridor between NW Africa and the Canary Islands at 600$1000 \mathrm{~m}$ and reaches $50^{\circ} \mathrm{N}$ at the Mid-Atlantic Ridge and $34^{\circ} \mathrm{N}$ in the GoC (Álvarez et al., 2004; Jenkins et al., 2015). Of the AAIW, up to $50 \%$ is detected near the Canaries and $30 \%$ in the GoC (Jenkins et al., 2015; Llinás et al., 2002). At $34^{\circ} 20^{\prime} \mathrm{N}$, in the south GoC, Louarn and Morin (2011) identified $90 \%$ of AAIW at $800 \mathrm{~m}$ and around $40 \%$ at $600 \mathrm{~m}$. AAIW is characterised by its high silicate and nutrient content, and salinity and oxygen minima (Jenkins et al., 2015).

Between 500 and $1500 \mathrm{~m}$, the northern path of the MOW flows along the Iberian margin (Ámbar and Howe, 1979; Ámbar, 1983; Borenäs et al., 2002). In its way out over the Straits of Gibraltar Sill, the upper-MOW appears below $150 \mathrm{~m}$, sinking to 400$600 \mathrm{~m}$ by $7^{\circ} 10^{\prime} \mathrm{W}$ (Ámbar, 1983). At this critical longitude, salinity decreases to 37, and the flow splits into three branches at depths of 400, 900 and $1200 \mathrm{~m}$ well defined at $7^{\circ} 40^{\prime} \mathrm{W}$. Downstream at Cape Santa Maria and Portimão canyon $\left(8^{\circ} \mathrm{W}\right)$, the three branches converge into the intermediate-MOW and the lower-MOW at 800 and $1200 \mathrm{~m}$, respectively (Ámbar and Howe, 1979; Iorga and Lozier, 1999, and references therein). The MOW then veers northwards after the Cape St. Vincent bathing the Portuguese margin up to western Europe where the salinity signal dilutes at $50^{\circ} 20^{\prime} \mathrm{N}$ (Alvarez et al., 2004; Arhan and King, 1995; Iorga and Lozier, 1999). Based on temperature and salinity, Zenk (1975) calculated the upper-MOW as composed of 32\% of Mediterranean Water and $68 \%$ of NACW. At $35^{\circ} \mathrm{N}, \mathrm{MOW}$ influences the establishment and intensification of the overlying Azores Current (Özgökmen et al, 2001; Rogerson et al., 2004; Volkov and Fu, 2010), and its surface entrainment into the GoC.

In contrast, in the southern half of the $\mathrm{GoC}$, it is well documented in oceanography that MOW is not channelled, but rather appears as mesoscale dynamic structures interacting with other water masses, capable of transferring mass, heat and momentum across the GoC (Carton et al., 2002; 2010; Richardson et al., 2000; Serra et al., 2010). The model of Serra et al. (2010) shows active meddy circulation at mid-depth, with the particular MOW dipole interaction with a cyclone spotted at $34-35^{\circ} \mathrm{N} / 8-9^{\circ} \mathrm{W}$. Carton et al. (2002) documented meddies at $34.5^{\circ} \mathrm{N} / 8.5^{\circ} \mathrm{W}$, and Quentel et al. (2011) reported a N-S (longitude $8^{\circ} 20^{`} \mathrm{~W}$ ) oceanographic section across the GoC, with in- and out-flows of salinity 36 in July. On the Moroccan margin, south of the Renard Ridge and Pen Duick Escarpment, $\left(35^{\circ} 17.60^{\prime} \mathrm{N} ; 6^{\circ} 49.56^{\prime} \mathrm{W}\right)$ Van Rooij et al. (2011) detected AAIW at mid depths of $684 \mathrm{~m}$ but no signal of salinities typical of the MOW, and Foubert et al. (2008) suggested a glacial/stadial meddy influence. Further south, however, Pelegrí et al. $(2005 \mathrm{a}, \mathrm{b})$ present evidence for the circulation of lower-MOW in the corridor between the Moroccan margin and the Canary Islands at the latitude of $29^{\circ} \mathrm{N}$ (Álvarez et al., 2005; Jenkins et al., 2015), with a clear seasonal distribution particularly intensified during winter, in a counter-balance with summer AAIW (Machín et al., 2010).

At higher depths than $1600 \mathrm{~m}$, below these intermediate water masses, flows the Eastern North Atlantic Deep Water (ENADW) (Ámbar et al., 1999).

\subsection{Geological setting}

In contrast to the well-established contourite depositional systems in the $\mathrm{N}$ of the $\mathrm{GoC}$ (e.g. Mougenot and Vanney, 1982; Llave et al., 2001; synthesis in Hernández-Molina et al., 2006), contourite drifts have rarely been addressed in the southern $\mathrm{GoC}$ along the 
Moroccan margin (Casas et al., 2010; Vancraeynest, 2015; Van den Berghe, 2015; Vandorpe et al., 2014; Van Rooij et al., 2011; Van Tornhout, 2017).

On the Faro Drift, an elongated mound drift of medium size (50 km long, 10-25 km wide, $300 \mathrm{~m}$ thick), three sandy layers have already been reported in the literature, yet with ambiguous ages around Termination 1a (16.5-14.5 kyr), YD (13.5-12 kyr) and late Holocene (6.8-2.9 kyr) (Ducassou et al., 2014; Faugères et al., 1985; Llave et al., 2006; Nelson et al., 1993; Rogerson et al., 2006; Sierro et al., 1999; Vergnaud-Grazzini et al., 1989). Our site GC01 was revisited during IODP-Expedition 339, as site U1386 $\left(36^{\circ} 49.685^{\prime} \mathrm{N} ; 7^{\circ} 45.321^{\prime} \mathrm{W}, 560.4 \mathrm{~m}\right)$ (Stow et al., 2013). New studies have therefore come up documenting the Faro Drift's longer record of contourites deposited by the upper-MOW during glacial and interglacial cycles. One of these showed a quite persistent and coherent pattern of deposition associated with Heinrich Stadials (HS) back to HS11 (Bahr et al., 2014). Previous work proposed that the Faro Drift was built with the contribution of stronger upper-MOW during the Holocene and stronger lowerMOW during the Last Glacial (Kaboth et al., 2016; Llave et al., 2006; Rogerson et al., 2006). Other authors referred to Holocene contourites deposited by intermittent stronger currents by the upper-MOW (Vergnaud-Grazzini et al., 1989) and shoaled lower-MOW (Schönfeld and Zahn, 2000) between 8-5.7 kyr, reaching their maximum after $4.8 \mathrm{ka}$.

On the Moroccan margin, TG2 was retrieved from the elongated contourite Drift (Suppl. Fig. S1) built south of the Renard Ridge and Pen Duick Escarpment. Contourites have been recorded in seismic profiles of the area (Vancraeynest, 2015; Van den Berghe, 2015; Vandorpe et al., 2014; Van Rooij et al., 2011; Van Tornhout, 2017). Not far south of TG2, lies site MD08-3227 (Van Rooij et al., 2011), described as homogeneous silty clay (de Jonge, 2010; Van Rooij et al., 2011). So far, AAIW has been invoked by these authors as precursor of the bottom currents responsible for the Moroccan Drifts build-up.

\section{MATERIALS}

This study is based on two cores. GC-01A-TC and GC-01A-PC (trigger and gravity cores respectively; $36^{\circ} 42,6257^{\prime} \mathrm{N} ; 7^{\circ} 44,7173^{\prime} \mathrm{W} ; 566 \mathrm{~m} ; 0.90 \mathrm{~m}$ and $5.21 \mathrm{~m}$ in length; site equivalent to IODP site U1386) and MVSEIS08_TG-2 $\left(34^{\circ} 58,28^{\prime} \mathrm{N} ; 6^{\circ} 50,47^{\circ} \mathrm{W}\right.$; $530 \mathrm{~m} ; 2.12 \mathrm{~m}$ in length), hereafter referred to as GC01 and TG2 respectively, are located in the northern and southern borders of the GoC (Fig. 1).

The two cores were recovered on contourite drifts identified from seismic profiles acquired onboard the R/V Sarmiento de Gamboa (CONTOURIBER-1 cruise; Hernández-Molina, 2011) and the R/V Bio-Hesperides (MVSEIS2008 cruise; UTM Report, 2008). These two cores are characterised by contourite facies. Identification of muddy- and silty-contourites in both cores was based on a detailed sedimentological analysis of visual description, digital images and colour parameters, sediment physical properties, geochemical element composition, sortable silt grain-size, stable isotopic geochemistry, and planktonic foraminifera assemblages (5.2).

A transect/series of Sea-Bird CTD cast stations supplied online by the British Oceanographic Data Centre (Natural Environment Research Council) were selected across the Moroccan margin to identify the presence of MOW along the southern GoC 
(Fig. 1). This transect from $34^{\circ} 12.2^{\prime} \mathrm{N}-7^{\circ} 36.3^{\prime} \mathrm{W}$ to $34^{\circ} 35.3^{\prime} \mathrm{N}-7^{\circ} 43.3^{\prime} \mathrm{W}$ comes from Cruise CD171, on board the RRS Charles Darwin in 2005.

All the data used in this study are archived at the PANGAEA data Publisher for Earth \& Environmental Science (http//:www.pangaea.de), and IRPARCUE paleoclimate database at IGME.

\section{METHODS}

\subsection{AMS dating}

For AMS ${ }^{14} \mathrm{C}$ ages, approximately $10 \mathrm{mg}$ of planktonic foraminifera species (Globigerina bulloides, Globigerinoides ruber-white, Globorotalia inflata, Globigerina falconensis, Globorotalia truncatulinoides and Orbulina universa) were picked in the fraction $>150$ or $>250$ micron (Table 1) at the IGME. Seventeen samples were analyzed at the Leibniz Laboratory for Radiocarbon Dating - Kiel, Germany, according to internal procedures (Nadeau et al., 1998). AMS radiocarbon ages Before Present (BP) were calibrated (Table 1) using the Calib program (Stuiver and Reimer, 1993) on-line version 6.0 (http://calib.qub.ac.uk) and the Marine09 calibration data (Reimer et al., 2009). Between 0-10.5 cal ka BP the Marine09 dataset is based on the Intcal09 tree-ring data that was converted with an ocean - atmosphere box diffusion model to yield ocean mixed-layer ages (Hughen et al., 2004). Beyond 10.5 kyr it uses marine coral and varve data with a mean global reservoir correction of 405 years (Reimer et al., 2009).

\subsection{Sediment geochemistry}

The content of a series of elements, included $\mathrm{Zr}(30 \mathrm{kV})$ and $\mathrm{Ca}, \mathrm{Al}, \mathrm{Si}, \mathrm{Fe}(10 \mathrm{kV})$ (Suppl. Fig. S2), were measured by non-destructive, continuous X-ray fluorescence (XRF) in cts (counts per second per unit area) every $1 \mathrm{~cm}$, using an Avaatech core scanner at the University of Barcelona. Data were processed through the WinAxiBatch software attached. For external calibration, the SMAR4 standard supplied by the Avaatech company (Analytical x-ray Technology, The Netherlands) was employed. The XRF core-scanner output is given in log-ratios. Ratios of elements are more insensitive to dilution effects in the interpretation of compositional changes down-core. Log-ratios have the advantage of surpassing the inherent non-linearity between relative intensities or counts and element concentrations, due to variable grain-size, geometry and inhomogeneity of minerals or water content in the sediment (Weltje and Tjallingii, 2008).

\subsection{Sortable Silt}

For sortable-silt 127 samples were analysed in the fraction $<63 \mu \mathrm{m}$. In these, organic matter was eliminated with $33 \%$ of hydrogen peroxide $\left(\mathrm{H}_{2} \mathrm{O}_{2}\right)$ and carbonates removed with $0.2 \mathrm{~N}$ hydrogen chloride $(\mathrm{HCl})$. Then, samples were dispersed with $0.5 \% \mathrm{Na}-$ hexametaphosphate (Calgon) and ultra-sonicated for 2 minutes. Prior to grain-size analysis in a Sedigraph Micromeritics III Plus, samples were homogenised by stirring in a magnetic plate for 30 minutes. The grain-size distribution was acquired in the interval 10-63 $\mu \mathrm{m}$, assumed to have non-cohesive behaviour during transport and deposition (McCave et al., 1995), at the IGME. The sortable silt mean of the carbonate-free 10-63 
$\mu \mathrm{m}$ interval is designated as $\overline{S S}$ (McCave et al., 1995). The percentage of sortable silt $(\mathrm{SS} \%)$, i.e. $\%(10-63 \mu \mathrm{m}) /<63 \mu \mathrm{m}$, is also a key parameter obtained from Sedigraph analyses. Dry-density required for the grain-size distribution calculation was measured by using a pycnometer Micromeritics Accupy 1330.

\subsection{Foraminifera counts and sea surface temperatures}

For planktonic foraminifera counts, $9-12 \mathrm{cc}$ of 68 bulk sub-samples were wet-weighed, freeze-dried, and re-weighed, then ultra-sonicated in a water bath, washed and sieved with tap and distilled water at the end through two grain-size fractions $(63-150 \mu \mathrm{m}$ and $>150 \mu \mathrm{m})$ at the IGME. These fractions were dried on paper filters in the oven at $40^{\circ} \mathrm{C}$ and weighed. Samples in the fraction $>150 \mu \mathrm{m}$ were split into adequate aliquots of at least 300-400 individuals for planktonic foraminifera census. The identification of species follows the taxonomy of Loeblich and Tappan (1964). Biogenic groups other than foraminifera and detrital minerals were counted in the same sample split.

To trace the temperature of the surface water masses, planktonic foraminifera species were counted and classified into four assemblages, following the studies in the area (Bé and Tolderlund, 1971; Hemleben et al., 1989; Kucera, 2007; Reguera, 2001, 2004): polar (Neogloboquadrina pachyderma), subpolar (Neogloboquadrina incompta, Neogloboquadrina pachyderma-dutertrei, Neogloboquadrina dutertrei, Globigerina bulloides, Turborotalita quinqueloba), transitional (Globorotalia uvula, Globorotalia scitula, Globorotalia glutinata, Globorotalia inflata, Orbulina universa, Globorotalia truncatulinoides, Globorotalia hirsuta) and subtropical (Globigerinoides ruber-white, Globigerinoides ruber-pink, Globorotalia crassaformis, Globorotalia aequilateralis, Globigerina rubescens, Globigerina falconensis, Globigerinoides trilobus, Globigerinoides sacculifer).

Counts of planktonic foraminifera $(>150 \mu \mathrm{m})$ were converted into Sea Surface Temperatures (SST) through a transfer function based on modern analogues; we applied SIMMAX28 (Modern Analogue Technique using a similarity index; Pflaumann et al., 1996; 2003). The database used is that of North Atlantic added with upwelling cells off NW Galicia and off NW Africa (Salgueiro et al., 2014). Past SST is estimated using a no-distance-weighted method (SIMMAX ndw), similar to the MAT technique but more robust (Telford et al., 2004). The output of Simmax28 gives a similarity of 0.9.

\subsection{Stable isotopes}

For stable $\mathrm{O}$ and $\mathrm{C}$ isotopes analysis, 25 planktonic and 10 benthic foraminifera of the species Globigerina bulloides and Cibicides pachyderma were picked primarily in the fraction $>250 \mu \mathrm{m}$, and occasionally in the interval 150-250 $\mu \mathrm{m}$, in 113 samples, at the IGME. The analyses were performed in a Finnigan MAT 252 mass spectrometer at Marum (University Bremen, Germany), coupled to an automated Kiel-carbonate preparation system. The long-term precision is $\pm 0.07 \%$ for $\delta^{18} \mathrm{O}$ and $\pm 0.05 \%$ for $\delta^{13} \mathrm{C}$ based on repeated analyses of internal and external (NBS-19) carbonate standards. The stable $\mathrm{O}$ and $\mathrm{C}$ ratios are expressed as $\delta$ in permil (\%o), relative to Vienna Peedee Belemnite (VPDB) standard. Nine duplicated samples in TG2 give a standard deviation between 0.07 and $0.12 \%$.

\subsection{Numerical simulations of ocean circulation}


To complement the observational record and test some of our hypotheses, we analyse the output from a numerical simulation carried out with an ocean general circulation model of the NEMO framework (Nucleus for European Modelling of the Ocean; Madec, 2008). The standard eddy-resolving model configuration has been setup within the DRAKKAR Consortium (e.g. Deshayes et al., 2013; Treguier et al., 2012), but in this study we consider the eddy-resolving version that was run in its global configuration (ORCA12) by the Marine Systems Modelling group at the National Oceanography Centre Southampton (e.g. Blaker et al., 2014; Duchez et al., 2014; Marzocchi et al., 2015). The model's horizontal resolution is $1 / 12^{\circ}$, with 75 vertical levels. The simulation has been initialised from the World Ocean Atlas (WOA) 2005 climatological fields (Antonov et al., 2006; Locarnini et al., 2006) and the run was started from rest in 1978, and then carried out for 30 years (1978-2007). A full description of this ORCA12 simulation is provided in Marzocchi et al. (2015). Thanks to its horizontal resolution, the model can resolve local mesoscale features such as the formation of meddies in the GoC (Drillet et al., 2005). In addition, the high horizontal resolution also provides a more realistic bathymetry in the Straits of Gibraltar, meaning that Mediterranean-Atlantic exchange does not require any parameterisations.

We have extracted physical properties such as sea surface temperature and salinity and current velocities from the model output for the period 2000-2007. The data analysed here is a climatology of the last eight years of simulation. We consider both seasonal and annual mean values of the analysed properties for a domain spanning between about $14-4^{\circ} \mathrm{W}$ and $31-39^{\circ} \mathrm{N}$ (Suppl. Fig. S3), at a depth of about $630 \mathrm{~m}$ (close to where the sediment cores have been recovered) and $860 \mathrm{~m}$ (close to where the MOW plume settles in the model; see Suppl. Fig. S4). The choice of specific depths is dictated by the model's vertical grid, which is refined at the surface ( $1 \mathrm{~m}$ at the first level) and then contains 22 levels in the first $100 \mathrm{~m}$, smoothly increasing to a maximum layer thickness of $250 \mathrm{~m}$ at the bottom (Marzocchi et al., 2015).

\section{RESULTS}

\subsection{Age model}

On cores GC01 and TG2, a number of oceanographic-climatic events such as HS1, the $\mathrm{YD}$ and the onset of the deglaciation leading into the Holocene were constrained by ${ }^{14} \mathrm{C}$ AMS ages (Table 1). The stratigraphy covering the last $22 \mathrm{kyr}$ is based primarily on fifteen AMS ${ }^{14} \mathrm{C}$ ages used as tie-points (Fig. 3A, B; Table 1), and additional correlation of high-resolution $\delta^{18} \mathrm{O}$ of $G$. bulloides curves from cores GC01 and TG2 with a chronostratigraphy from a nearby location in the mid-Northeast Atlantic Iberian margin (MD01-2444 in Martrat et al., 2007). Given the presence of reversals at $1.27 \mathrm{~m}$ and 1.43 $\mathrm{m}$ in $\mathrm{GC} 01$, these two ages were ignored and the interval was interpolated between 0.93 $\mathrm{m}$ and $1.88 \mathrm{~m}$. Yet, the differences between measured and interpolated ages for the rejected depths were $270 \pm 70 \mathrm{yr}$ and $428 \pm 30 \mathrm{yr}$. The trigger core of GC01 does not link with its piston core, showing a gap between 8-9 kyr (Fig. 3A). Event HS1 was dated 18.6-15.5 kyr (for agreement with other cores in the area see compilation by Rogerson et al., 2010) and the YD, 13.7-11.9 kyr. Whenever possible, we dated the top and/or base of silty-contourite units (defined in section 5.2) (Table 2).

\subsection{Facies and contour-currents}


Cores GC01 and TG2 contain two distinct facies that we classified as muddy- and siltycontourites, following structural, textural and compositional criteria. These facies agree with the diagnostic criteria of the original facies described by Gonthier et al. (1984), Stow (1985), Stow et al. (2002), and Stow and Faugères (2008).

The muddy-contourites are uniform, unstructured, highly bioturbated and unsorted facies. Fine grain size smaller than $63 \mu \mathrm{m}$ represents more than $90 \%$ of the total sediment (Suppl. Table 1). The sand fraction $(>63 \mu \mathrm{m})$ consists of a mixture of primary biogenic and terrigenous particles in a proportion of 98:2 (fraction $>150 \mu \mathrm{m}$ ). The silty-contourites are instead structured, though also unsorted facies. The siltycontourites in our records present basal intensively bioturbated muds, which coarsen upwards to discontinuous silty mottled lenses in clay, and coarser sandy silt in the middle of the sequence with no primary laminations (unless destroyed by bioturbation), then fining upwards in an inverse, mirrored gradational sequence. The whole cycle contains disperse carbonate shell fragments and lower and upper gradational contacts. They vary from a few centimetres up to $0.43 \mathrm{~m}$ in thickness (Fig. 3C,D; Table 2). The thinner units, however, do not exhibit the full sequence. In terms of texture, the percentage of fine fraction $<63 \mu \mathrm{m}$ is similar to the muddy-contourites, and slightly higher for core TG2 (Suppl. Table 1). Yet, for the silty-contourites dated YD/HS1, the SS\% nearly doubles that of the muddy-contourites (Suppl. Table 1). The proportion of biogenic grains in the fraction $>150 \mu \mathrm{m}$, which is mainly foraminifera shells, is comparable to the muddy-contourites. These values are also similar to both sites in the $\mathrm{N}$ and $\mathrm{S}$ of the GoC. Because the sediment bulk composition contains a ratio of $40-50 \%$ $\mathrm{SiO}_{2}: 12-20 \% \mathrm{CaO}: 10 \% \mathrm{Al}_{2} \mathrm{O}_{3}$, we classified these facies as (silici)clastic silty and muddy-rich contourites (Stow and Faugères, 2008).

The contourite facies present other distinctive characteristics between silty-contourites and interspersed muddy-contourites, as illustrated in Suppl. Fig. S2 for the Moroccan and Iberian margins. The bi-gradational silty-contourite sequence is well defined by sediment physical properties with increasing Pw-velocity and density, as well as decreasing reflectance into its middle (Suppl. Fig. S2A-C). The lower and upper limits of the silty-contourites into the muddy-contourites are in fact marked by decreases in grain-size and geochemical composition. Sharp changes are shown in sortable silt $(\overline{S S})$ with a difference of 17 to $10 \mu \mathrm{m}$, as well as $\mathrm{Zr} / \mathrm{Al}, \mathrm{Fe} / \mathrm{Al}, \mathrm{Ca} / \mathrm{Fe}$ and $\mathrm{Si} / \mathrm{Ca}$ ratios, compared to background values (Supp. Fig. S2D-H).

In core GC01, $\overline{S S}$ increases clearly from a background value of 10-15 $\mu \mathrm{m} \overline{S S}$ up to 20-30 $\mu \mathrm{m}$ in the silty-contourites, with enhanced flow during HS1 than YD (Fig. 4A). After 6 ka to present, $\overline{S S}$ remains constant and high around $27 \mu \mathrm{m}$. The percentage of fraction $10-63 \mu \mathrm{m}$ (silt) over $>63 \mu \mathrm{m}$ ( $\mathrm{SS} \%$ ) is also greater in all silty-contourites, and particularly at HS1 and YD. In core TG2, $\overline{S S}$ increases to $18.3 \mu \mathrm{m}$ during the YD and deglaciation, but is lower during the Holocene $(17 \mu \mathrm{m})$ (Fig. 4B, Suppl. Table 1). The SS\% follows the tendency seen above, remarkably for the silty-contourites identified during the YD. Cross-plots of $\overline{S S}$ versus SS\% have been proved useful confirmation when dealing with current-sorted sediments (McCave et al., 2006; Roberts et al., 2017). In the case of core GC01, all sediments are very poorly sorted (Suppl. Fig. S5A). The best fit equation shows $\mathrm{R}^{2}=0.34$ for all sediments altogether, but $\mathrm{R}^{2}=0.18$ and $\mathrm{R}^{2}=0.002$ if muddy- and silty-contourites are discriminated. TG2 shows even more unsorted sediments (Suppl. Fig. S5B). However, if we select only the $50 \%$ of maximum values of 
$\overline{S S}$ per each of the four silty contourites, that is their peaks, then TG2 $\left(\mathrm{R}^{2}=0.77\right)$ presents better sorting than GC01 $\left(\mathrm{R}^{2}=0.0009\right)$ (Suppl. Fig. S5C, D).

The northern site (core GC01) shows four silty-contourites that we named I6, I5, I2 and I0, where $I$ stands for the Iberian margin, from deglacial to Holocene times through the composite record of the piston core (PC) and trigger core (I0 in TC) (Table 2). Core TG2 also contains four silty-contourites named M5, M4, M3 and M1, where $M$ stands for the Moroccan margin, again ordered from past to present. As the number is associated with age, equal numbers imply contemporary silty-contourites at both sites (eg. I5 and M5). We could not use the nomenclature assigned in Faugères et al. (1986) and Stow et al. (1986) for the Faro Drift because it is in reversed chronological order (higher number for the youngest event in age), not allowing us to add new geological events back in time, as necessary for the silty-contourites concurrent with HS1 identified in our core GC01. Yet, Table 2 includes a correlation with the "peak contourites" set in Faugères et al. (1986) and Stow et al. (1986).

The record from GC01 reveals then four consecutive silty-contourites (I6, I5, I2, I0) over the last $22 \mathrm{kyr}$, with the only uncertainty over the gap-interval 8-9 kyr (Fig. 3B). Silty-contourite I6 occurs during HS1, I5 during the YD, I2 at the onset of the Holocene, and I0 during the most recent Holocene, between 3.7-1.5 kyr (Table 2). Core TG2 has a continuous record starting from $14 \mathrm{ka}$ up to the late-Holocene, where four silty-contourites (M5, M4, M3, M1) have also been identified (Fig. 3B). M5, M4, and M3 occur during the YD, and M1 at 7.4-6.3 kyr (Table 2).

The duration of the silty-contourites deposition was calculated based on the age attributed to the bottom and top of each individual unit, as estimated above (Table 2). At the Iberian site, sedimentation rate of silty-contourites is almost halved from deglacial times to the Holocene, and even higher differences were estimated for the Moroccan site (Table 2). The duration of silty-contourites on both the $\mathrm{N}$ or $\mathrm{S}$ sides of the GoC varies between 100 and 2200 years (Table 2).

\subsection{Planktonic foraminifera assemblages and Sea Surface Temperatures}

For the Last Glacial, we found 55\% of polar and subpolar assemblages altogether and $10 \%$ of subtropical assemblages. In the deglaciation, results from core GC01 show dominant polar (7\%) and subpolar (73\%) assemblages during HS1 (Fig. 5A). The YD instead presents only $62 \%$ and $46 \%$ subpolar for both the $\mathrm{N}$ and S sites, respectively. Warm intervals like the Bølling/Allerød (B/A) (only GC01) and the Holocene show 16$30 \%$ of the subtropical assemblage. The Holocene Climatic Optimum, with $25 \%$ subtropical decreasing to $20 \%$ from $6 \mathrm{ky}$ to present, is better identified at the Iberian than the Moroccan site.

The SST reconstructions based on the Simmax-transfer function of these planktonic foraminifera show a persistent difference of $4-5^{\circ} \mathrm{C}$ temperatures between winter and summer (not shown) along the full records (Fig. 5B). In the northern site, the Last Glacial reflects an average difference of $3^{\circ} \mathrm{C}$ compared to the Holocene. Across HS1, two climate phases are also clearly identified in GC01, where the oldest yields $16.5^{\circ} \mathrm{C}$ (s) and $12^{\circ} \mathrm{C}(\mathrm{w})$, and the youngest and colder $10^{\circ} \mathrm{C}(\mathrm{s})$ and $6^{\circ} \mathrm{C}(\mathrm{w})$. The $\mathrm{B} / \mathrm{A}$ interval in GC01 is characterised by a stable temperature around $21^{\circ} \mathrm{C}$ for summer (s) and $16^{\circ} \mathrm{C}$ for winter (w), and on average about $1^{\circ} \mathrm{C}$ colder. During the YD, a sequential warm-cold phase pattern is shown, where SSTs decrease first to $12^{\circ} \mathrm{C}(\mathrm{w})$, and then down to $8^{\circ} \mathrm{C}$ 
(w). Similar temperatures to the B/A interval are found during the Holocene. By contrast, in core TG2 a general cold phase, $9^{\circ} \mathrm{C}(\mathrm{w})$, is shown at the $\mathrm{YD}$, interrupted with a $14{ }^{\circ} \mathrm{C}(\mathrm{w})$-warm peak in its middle. The Holocene in TG2 shows similar SSTs of GC01. The most important discrepancy between SSTs in the northern and southern records occurs at the onset of the YD (13-14 kyr) with a difference of $7^{\circ} \mathrm{C}$ between both margins (Fig. 5B), marked by coherent percentage of cold-thriving species G. scitula (Fig. 5C).

Analysis of $\delta^{18} \mathrm{O}$ of planktonic foraminifera gives insights into the EvaporationPrecipitation (E-P) balance. Heavier $\delta^{18} \mathrm{O}$ isotopes of $\mathrm{G}$. bulloides could indicate either colder waters or higher E-P (saltier waters). The difference in $\delta^{18} \mathrm{O}$ between the Last Glacial $(1.9 \%$ ) and the Holocene $(0 \%)$ is $1.9 \%$ in core GC01, while the difference between the Holocene and the YD is 1.5\% in GC01 and 0.3-1.3 \%o in TG2 (Fig. 5D). Very short periods with lighter $\delta^{18} \mathrm{O}$ values are evident during extreme climatic events, such as HS1 and the YD (exceedingly enhanced in TG2), indicating fresher-water input, which is supported by the cold surface temperatures derived from the planktonic foraminifera species (Fig. 5D).

\subsection{Benthic $\mathrm{C}$ and $\mathrm{O}$ stable isotopes and contourites signal}

Ocean ventilation is examined by looking at changes in $\delta^{13} \mathrm{C}$ of benthic foraminifera. For core GC01, the $\delta^{13} \mathrm{C}$ of benthic C. pachyderma averaged $1.0 \%$ during the Last Glacial, was as light as $0.6 \%$ in the HS1 (18.5-15.5 kyr), $0.8 \%$ in the YD, and increased to 1.0-1.2\%o during the Optimum- and late-Holocene (Fig. 6A). This curve follows a common pattern for the upper-MOW along the northern path in the GoC and along the Portuguese margin (Schönfeld and Zahn, 2000; Vergnaud-Grazzini and Pierre, 1991). GC01 is also comparable to the lower-MOW in the GoC (Voelker et al., 2006) during the warm periods of $\mathrm{B} / \mathrm{A}$ and the Holocene, but a positive offset of $0.3 \%$ is shown for the Last Glacial and HS1, and of $0.2 \%$ for the YD. In the southern side of the $\mathrm{GoC}$, TG2 average values are usually approximately $0.2-0.4 \%$ lighter, showing values of $0.4 \%$ for the YD and up to $0.7-1.0 \%$ for the Holocene. On top of this general pattern, Iberian I6, I5, I2 and I0, as well as Moroccan M5, M4, M3 and M1 siltycontourites seem to exhibit relatively slightly heavier values (Fig. 4C).

The overall curve of $\delta^{18} \mathrm{O}$ of benthic foraminifera C.pachyderma of the upper-MOW shows values of 3.4\% during low sea-level glacial period and depleted 2.0-2.2\%o values over the high-stand Holocene (Fig. 6B), approximately $0.75 \%$ lighter than the North Atlantic (Curry and Oppo, 2005) and the lower-MOW in the GoC (Voelker et al., 2006). HS1 values vary to $3 \%$, YD to $2.7 \%$ and the $\mathrm{B} / \mathrm{A}$ to $2.5 \%$. Compared to GC01, TG2 is lighter during the YD and slightly heavier for the last $11 \mathrm{ky}$.

\subsection{Ocean model}

In order to investigate the distribution of MOW N and S of Gibraltar, we have also analysed the output of a high-resolution global ocean model. Seasonal images of salinity and current velocity (Autumn: September-October-November average; Winter: December-January-February average) clearly show both the spreading of MOW into the North Atlantic and the different circulation patterns during these two seasons at 857 mwd (Fig. 7). The chosen depths are dictated by the model's vertical levels, and these would broadly represent circulation features both at the depth at which the sediment 
cores have been recovered (shallower) and where the MOW plume settles in the model (deeper).

The patterns of temperature and salinity distributions exhibit minimal seasonal differences (Fig. 7) and are generally well represented by the annual mean values (Suppl. Fig. S4).

Current velocities in spring and summer (not shown), autumn (Fig. 7A) and annual mean (Suppl. Fig. S4) highlight the existence of a northward flow of fresher (salinity below 35.9) waters to the south of the Straits of Gibraltar. However, winter circulation patterns show the presence of a southward-flowing current along the Moroccan coast, supposedly of Mediterranean origin (Fig. 7B, Suppl. Fig. S3B). We cannot exclude that this could simply represent a recirculation feature of North Atlantic origin (as it appears to be at shallower depths), but below 850 mwd an additional weaker (velocities up to about $0.05 \mathrm{~m} / \mathrm{s}$ ) branch of outflow appears to flow south from the Straits of Gibraltar and join the stronger current extending south of $34^{\circ} \mathrm{N}$ (Fig. 7B). These simulations could, therefore, support the physical dynamics of a possible branch of MOW flowing southward. In addition, a salinity cross section in the $\mathrm{GoC}\left(\sim 7^{\circ} \mathrm{W}\right.$; Fig. $\left.7 \mathrm{C}\right)$ clearly shows the presence of a more saline (above 36.2) water mass, descending from 600 to 1000 mwd along the Moroccan margin. These circulation patterns are consistent throughout the year (not shown), not only during the winter months (as shown in Fig. $7 \mathrm{C}$ ), and in different years of the simulation.

\section{DISCUSSION}

\subsection{Nature of drift build-up on the north and south margins of the Gulf of Cadiz}

Similarities between paleoceanographic records extracted from contourite drifts and open ocean records raise concerns about the steadiness of the processes contributing to the formation of sediment drifts. Previously accepted interpretations and paradigms (Faugères et al., 1984; Stow and Lovell, 1979) have lately been subject of considerable debate and re-evaluation (Rebesco and Camerlenghi, 2008; Rebesco et al., 2014). While the association of bottom currents with paleo-oceanographic processes is wellestablished, the distinction of facies is not always straightforward. In our records, we were able to identify unstructured facies that we named muddy-contourites, and structured individual silty-contourites following Stow and Faugères (2008) and Stow and Lovell (1979). Most of this $90 \%$ clay and silt sediment, is probably supplied by downslope processes in the continental margin, especially turbidity currents and lutite nepheloid flows; these inject clouds of sediment into the water column, some of which is then entrained by the along-slope flows, to be eventually deposited as contourites. Periodic increases and decreases in the slope currents resuspends and redeposits this sediment and concentrates it in contourite drifts. Contourites are, in turn, the result of fine-grained sediments eroded, transported and redeposited by semi-permanent bottom currents (eg. Stow et al., 1985; Stow and Faugères, 2008; Rebesco et al., 2014). Periodic increases in $\overline{S S}$ reflect sediment selectively deposited by fast contour-currents capable of transporting non-carbonate medium to very coarse silt (Fig. 4). The origin of the higher proportion of finer mud is achieved by selective deposition of resuspended fine sediment (McCave and Hall, 2006). Estimation from $\overline{S S}$ according to a recent calibration (McCave et al., 2017) yields peak flow speeds around $\sim 15 \mathrm{~cm} / \mathrm{s}$ for siltycontourites deposited either during short cold events (HS1, YD) or the Holocene (Suppl. Table 1). In the Moroccan margin, the pattern for silty-contourites is similar but speed 
decreases to $\sim 7 \mathrm{~cm} / \mathrm{s}$. Thus, what we considered muddy-contourites seems to record slow contour-currents (Suppl. Table 1), although the facies do not record any sort of flow structures. At the orbital scale, the current is enhanced with $\overline{S S}$ of $25 \mu \mathrm{m}$ in the Holocene compared to $12.5 \mu \mathrm{m}$ during the glacial period at GC01 (Fig. 4A); this would correspond to an increase in flow speed of $16 \mathrm{~cm} / \mathrm{s}$ according to the same calibration (McCave et al., 2017) (Suppl. Table 1). Our results of sortable silt would further not only corroborate but also quantify the hypothesis of a weaker glacial but stronger Holocene Mediterranean upper outflow (Hernández-Molina et al., 2013; Kaboth et al., 2016; Llave et al., 2006; Rogerson et al., 2006).

To regard the sediment referred to muddy-contourites as slow-contourites, contrasted with fast-contourites, we cross-plotted $\overline{S S}$ vs SS\% which could indicate a very poorly sorted signature, or a moderately well sorted signature. Results revealed very poorly sorted sediments with $\mathrm{R}^{2}{ }_{\mathrm{MC}}=0.1827$ in $\mathrm{GC} 01\left(\mathrm{R}^{2} \mathrm{SC}=5 \mathrm{E}-06\right.$, in TG2) (Suppl. Fig. S5A, B). More puzzling are the facies interpreted as fast contour-currents (silty-contourites) by high $\overline{S S}$ and flow speed in the $\mathrm{N}$ and $\mathrm{S}$ of the GoC, which originate from an unsorting (MOW) current. Nonetheless, Mediterranean Outflow currents velocities have been measured and are widely assumed as such in the literature. Remarkably though our results show better, but no significant, sorted silty-contourite facies in core TG2 (Moroccan Drift) than GC01 (Faro Drift), as well as sometimes (GC01) better sorted muddy- than silty-contourites (Suppl. Fig. S5). If all the deposition is current-controlled, as expected from a contourite drift, why are fast- and slow-currents depositing unsorted facies?

Muddy- and silty-contourites are definitely limited by marked sharp changes evidenced by sedimentological composition (Suppl. Fig. S2). The concentration of Zr co-varies with elements, like Fe, Ca and Si (Suppl. Fig. S2). Zr concentrated in heavy minerals is particularly abundant in the older silty-contourites (Fig. 4), suggesting both better sorting in relation to aluminosilicates (Suppl. Fig.6A, C), and faster currents (Suppl. Fig. S6B, D) depositing silty-contourites during the deglaciation than the Holocene (Fig. 4A, B). In this case, the relationship supports sorting in fast-currents. In addition, the abundance of $\mathrm{Zr}$ could indicate a more direct supply of coarser terrigenous sediment from the shelf edge at lower sea-level, or higher proportion of allogenic (terrestrial) over authigenic (carbonate) sediment flux entrained by the plume from the Guadalquivir and associated rivers (Sierro et al., 1999). At site TG2, it can be noted that is only about 50 $\mathrm{km}$ away from the shelf edge and that is likely to put it in range of direct shelf export from the upper water column, as well as within bottom lutite flows. In this case, the finer sediments might represent less well sorted supply from the shelf under a slow along-slope current and the so-called silty-contourites would represent a greater degree of reworking, producing a coarser size signature.

In summary then, two types of facies can be distinguished, based on $\%$ fines, biogenic content, $\overline{S S}, \mathrm{SS} \%$ and changes in chemical composition. We interpret the siltycontourite units as deposited during intervals of higher flow velocity, interspersed with times of deposition at lower velocity, i.e. muddy-contourites. Nonetheless, the whole sequence is contouritic in character. Drifts were built by continuous, long-term, alongslope, bottom current processes with extremely variable flow velocity.

The close resemblance of the facies on opposite margins of the GoC (GC01 and TG2), supports the presence of contour-currents and contourite drifts also along the Moroccan margin (Suppl. Fig. S1). Fast contouritic currents flow at double speed in the $\mathrm{N}$ than $\mathrm{S}$ 
margin (Suppl. Table 1); faster currents along the $\mathrm{N}$ margin can also be identified in the ocean model (see Figure 7).

\subsection{Origin of contourites in the Gulf of Cadiz - a southwards branch of Mediterranean Outflow?}

The view of MOW as a geostrophic current strengthened by Coriolis deflection, following bathymetry, and veering northwards along the Iberian margin is a wellconfirmed hypothesis (Ámbar and Howe, 1979; Ámbar, 1983; Borenäs et al., 2002). The GoC Contourite Depositional System, and in particular the Faro Drift, have been extensively characterised both morphologically and seismically and is confirmed beyond reasonable doubt to be built by MOW-currents (Faugères et al., 1985; Hernández-Molina et al., 2003, 2006; Llave et al., 2001, 2006; Mougenot and Vanney, 1982). By contrast, fewer seismic records and ground-proofing sediment cores exist in the southern margin of the GoC. TG2 fills this gap, allowing us to investigate the origin of the currents responsible for the deposition of the Moroccan drifts. This can be compared to the system in the northern $\mathrm{GoC}$ along the Iberian margin, using cores TG2 and GC01.

Voelker et al. (2006) interpreted heavier $\delta^{13} \mathrm{C}$ of $C$. pachyderma in the lower-MOW in the $\mathrm{GoC}$ as a tracer of higher MOW export occurring during cold millennial climate events, and as an indicator of better ventilation in the Alboran Sea and GoC, resulting from vigorous glacial deep-convection of WMDW (Western Mediterranean Deep Water) mainly in the Gulf of Lions (W Mediterranean).

In our results from the upper-MOW (GC01), the $\delta^{13} \mathrm{C}$ of C. pachyderma of the Last Glacial (1.0\%) is more depleted than glacial in both the deep GoC (MD99-2339) and the deep western Mediterranean (MD95-2043). But in GC01the Last Glacial is also slightly more depleted than the Holocene (1.2\%o) (Fig. 6A). This pattern of upper-MOW resembles more that of intermediate waters in the North Atlantic, which have higher Holocene benthic $\delta^{13} \mathrm{C}$ values relative to the Last Glacial (Curry and Oppo, 2005; Sarnthein et al., 1994) than the deeper WMDW (Sierro et al., 2005; Voelker et al., 2006). At present, the WMDW contributes only $30 \%$ to the MOW (Bethoux, 1979; Broecker, 1991; García Lafuente et al., 2007; Rogerson et al., 2012). In some years of mild winters, no WMDW exits the Straits of Gibraltar at all (Millot, 2009). Moreover, WMDW is essentially a thermally-circulated water mass, whereas two thirds of the buoyancy loss from the Mediterranean basin arises from evaporation (Bethoux, 1979; Rogerson et al., 2012). Therefore, our $\delta^{13} \mathrm{C}$ of $C$. pachyderma record of GC01 may link the water cycle forcing southeast the Straits of Sicily through its influence on the water which contributes the majority of MOW, ie. Levantine Intermediate Water (Millot, 2009; Rogerson et al., 2012). According to the three-layer formulation of the exchange at Gibraltar (Millot, 2009), there is a physical constraint given by the effective stagnation depth at $800 \mathrm{~m}$ to suck Mediterranean water through the Straits of Gibraltar (Rogerson et al., 2008). Therefore, the Mediterranean Intermediate Water is left as the highest contributor to MOW driving the record in the GoC (Millot, 1999; Rogerson et al., 2012), though changing in tandem with WMDW (Rogerson et al., 2008; Toucanne et al., 2012). Assuming the direct relationship of more positive $\delta^{13} \mathrm{C}$ with increasing salinity, the gradient of glacial benthic $\delta^{13} \mathrm{C}$ observed in Fig. 6A (purple shading) indicates a more substantial export of Mediterranean waters to the GoC through the lower-, rather than the upper-, MOW during cold periods (Last Glacial, HS1, YD), when sea level is lower. At the onset of the B/A and the Holocene, both the lower- and 
upper-MOW intensified simultaneously after both HS1 and the YD, persisting then over the entire warm periods with identical benthic $\delta^{13} \mathrm{C}$ signatures (Fig. 6A). This stronger MOW during the Holocene, in contrast to the Last Glacial, is also supported by higher $\overline{S S}$ (Fig. 4A, B) (section 6.1).

In addition, a relatively heavier $\delta^{13} \mathrm{C}$ signal found in the silty-contourites suggests that these carry an even more positive benthic $\delta^{13} \mathrm{C}$ signal, supported by higher abundance of $\mathrm{Zr}$, and $\overline{S S}$ and $\mathrm{SS} \%$ (Fig. 4A, B), as a response to millennial variability. At this scale, our findings for the upper-MOW validate those reported for the lower-MOW on core MD992339 (Voelker et al., 2006), and the Levantine Mediterranean Water (LIW) on MD012472 in the Corsica Trough (Toucanne et al., 2012) where larger grain-size correlated with heavier benthic $\delta^{13} \mathrm{C}$, identifying MOW as the water mass depositing the contourites. In our case, high $\overline{S S}$ indicates intense contour-currents not only in the well-established Iberian drift, but also along the Moroccan margin (Fig. 4A, B). On millennial scales, the MOW contour-current was enhanced during cold, short, abrupt climatic events, such as HS1 (record available just for GC01) and YD (synchronous for the northern and southern margins) in the deglaciation, and slightly more pronounced during the mid-Holocene (Morocco) and early and late-Holocene (Iberia) (Fig. 4A, B; Suppl. Table 1). The emplacement of silty-contourites during the Holocene might coincide with oscillations of around $0.4 \%$ of benthic $\delta^{13} \mathrm{C}$ occurring at $2.8 \mathrm{ka}$ (I0), $5 \mathrm{ka}$ or $9.3 \mathrm{ka}$ (I2) due to the reorganization of deep-waters in the Atlantic (Oppo et al., 2003).

A common source can be further hypothesised for the currents depositing siltycontourites along both margins, given the similar trends found in the $\delta^{13} \mathrm{C}$ signal of benthic $C$. pachyderma at $550 \mathrm{~m}$ at both GC01 and TG2 sites, pointing to the presence of MOW along the northern margin of the GoC as well as the south (Fig. 6A). The $0.2 \%$ offset of lighter values in $\delta^{13} \mathrm{C}$ benthic on the Moroccan side (Fig. 6A) reflects most probably mixing with higher proportion of modified-Atlantic water. The constant $0.2 \%$ offset is perturbed by an increased gradient in $0.7-0.4 \%$ between the two margins during the first half of the YD and a short period around $6 \mathrm{ka}$, respectively. This is likely due to the penetration of the nutrient-rich Azores Front eastwards into the GoC and consequent resupply of light carbon to surface waters (Rogerson et al., 2004). This pattern is sustained by peaking of cold planktonic foraminifera G.scitula, commonly associated with the Azores Front (Rogerson et al., 2004) during the two intervals (Fig. 5C), and could explain the thermal gradient of $4^{\circ} \mathrm{C}$ temperature that cools the first half of the YD in the Moroccan margin (Fig. 5B). The strength and position of the Azores Front is, therefore, expected to affect locally and occasionally the GoC surface water temperatures.

Numerical simulations of the present-day ocean suggest that the existence of a countercurrent flowing southward is physically possible (Fig. 7B). During the winter months, the simulated MOW appears to exit the Straits of Gibraltar not only flowing northward (current velocities above $0.5 \mathrm{~m} / \mathrm{s}$ ), but also southward, even though exhibiting relatively low current velocities (up to $0.05 \mathrm{~m} / \mathrm{s}$ ) (Fig. 7B). In autumn, another water mass flows northward from the South Atlantic along the NW African coast, entering the GoC along the Moroccan margin, with current velocities of about $0.05 \mathrm{~m} / \mathrm{s}$ (Fig. 7A). This most likely represents modified-AAIW (Louarn and Morin, 2011; Machín et al., 2010). Modelled current velocities do not always correspond to the wide range of values displayed in the literature (e.g. McCave, 2008; Mulder et al., 2003; Stow and Lovell, 1979) and would at times appear too weak to re-suspend material for subsequent deposition; nonetheless, these represent potential current directions. 
The Atlantic Ocean Atlas shows higher salinities between $25^{\circ} \mathrm{N}$ and $45^{\circ} \mathrm{N}$ (e.g. Figure 8 in Van Sebille et al., 2011). Given the dominance of meddies in this area (Carton et al., 2002; 2010; Iorga and Lozier, 1999; Quentel et al., 2011; Richardson et al., 2000; Rogerson et al., 2011; Serra et al., 2010), substantial horizontal diffusion, stirring and mixing would likely fill the entire GoC. Therefore, although the dominant branch of Mediterranean Outflow with highest velocities flows north, this does not mean that outflow water cannot be found to the south, because it may be transferred through entrainment with other currents or recirculation features. At the depth where the plume settles, Coriolis Force does not dominate and MOW expands in the whole GoC (Suppl. Fig. S7). Today, channeled MOW is detected at $300-450 \mathrm{~m}$ and $6^{\circ} 10^{\prime} \mathrm{W}$ in the central GoC directly from the Straits of Gibraltar (Hernández-Molina et al., 2014), before any turn occurs. This branch could potentially veer southwards. Today's ocean shows clear presence of saltier water in a transect between $700-1400 \mathrm{~m}$ at $34^{\circ} 20^{\prime} \mathrm{N}-7^{\circ} 40^{\prime} \mathrm{W}$ along the Moroccan margin (Fig. 1C). Apart from the oceanographic evidence, the existence of a lower-MOW towards the Moroccan margin has also been previously documented in paleoceanographic records (Sarnthein et al., 1994; Zahn et al., 1987). The circulation patterns simulated by the eddy-resolving ocean model during the winter months (especially below $850 \mathrm{~m}$ ) appears to validate the physical possibility of a southward turning MOW (Fig. 7B, Suppl. Fig. S3B, Fig. 2,1)). The present simulations are carried out with a global ocean model, but provide a good representation of the circulation patterns in the regions of interest. Further insight could be gained by using regional models at higher resolution, and sensitivity experiments could be designed to test our hypotheses in more detail, though this is beyond the scope of this work.

Based on the above paleoproxies and oceanographic evidence, we reconstruct the MOW circulation history in the GoC N and S drifts for the last $22 \mathrm{ky}$. During MIS2 low sea level, sluggish upper-MOW flowed out of the Gibraltar gateway at a $\sim 12.5 \mathrm{~cm} / \mathrm{s}$ speed. In contrast, during the deglaciation fast upper-MOW contour currents deposited siltycontourite I6 $(\sim 25 \mathrm{~cm} / \mathrm{s})$ at the HS1 northward along the Iberian margin (no record is available for the southern side), and deposited I5 and M5 ( 25 and $18 \mathrm{~cm} / \mathrm{s})$ over the YD towards both the northern and southern margins as well as short-lived M4 and M3 on the Moroccan margin. During the Holocene high sea-level, when maximum exchange over the Gibraltar Sill is expected (Rohling and Bryden, 1994; Rogerson et al., 2012), the upper-MOW speeds up to $\sim 25 \mathrm{~cm} / \mathrm{s}$ to $\mathrm{N}$, and $\sim 18 \mathrm{~cm} / \mathrm{s}$ to $\mathrm{S}$, with $\Delta 0.3$ $\mathrm{cm} / \mathrm{s}$ increase for three particular silty-contourites, I2 and I0 along the Iberian margin and M1 on the Moroccan side (Fig. 4). On the Moroccan margin, however, North Atlantic waters like modified-AAIW or NACW entrained the MOW.

Of the three hypotheses proposed for the deposition of silty-contourites along the Moroccan margin (Fig. 2), we provide evidence $\left(\delta^{13} \mathrm{C}\right.$ of $C$. pachyderma, $\overline{S S}, \mathrm{CTD}$, ocean model) for a southern branch of the upper-MOW in the GoC, i.e. hypothesis 1 , which has not been reported before. A conclusive validation of this hypothesis would ultimately require measurements of paleocurrent directions.

\subsection{Millennial-variability: timing, duration and oceanographic context of contourite deposition by the upper-MOW}

Our results show the deposition of silty-contourites synchronous with well-defined North Atlantic climatic events, such as HS1 and the YD. Both cold events are connected with either abrupt discharge of icebergs and/or cold surface circulation in the North Atlantic Ocean (Bond et al., 1993; Fairbanks, 1989; Stanford et al., 2006). The age of 
the eight silty-contourites found is controlled by ${ }^{14} \mathrm{C}$ AMS dating (Table 1, Table 2). In the GoC, silty-contourites I6, M5 and I5 occurred at times with abundant polar and subpolar planktonic foraminifera, due to the cooling of surface waters' winter temperatures down to $6-9^{\circ} \mathrm{C}$ (Fig. 5B). Silty-contourites M4 and M3 were deposited towards the end of the YD and the deglaciation, with only $46 \%$ of polar and subpolar foraminiferal assemblages at times of relatively cold surface water temperatures of $14^{\circ} \mathrm{C}$, and more positive $\delta^{18} \mathrm{O}$ values. During the Holocene, subpolar assemblages were reduced to $36 \%$, replaced by subtropical species, because SST increased to $17^{\circ} \mathrm{C} \pm 1$, notwithstanding the relatively variable $\delta^{18} \mathrm{O}$ of G. bulloides (Fig. 5A, B, D). Despite the stable temperature of the Holocene, three silty-contourites were deposited at 10-9.4 kyr (I2), 7.4-6.2 kyr (M1) and 3.7-1.5 kyr (I0), possibly coincident with slightly colder and short episodes in the North Atlantic (Oppo et al., 2003; Wanner et al., 2011). Our records thus verify the deposition of contourites by the upper-MOW contourcurrent associated with cold HS1 and YD climatic and paleoceanographic events for the Iberian margin (Llave et al., 2006; Rogerson et al., 2010; Toucanne et al., 2007). These silty-contourites deposited by the upper-MOW are also coeval with silty-contourites deposited by the lower-MOW during MIS-3 Heinrich stadials (MD99-2339, 1170 m; Voelker et al., 2006). The IODP U1387 site, at a location close to GC01, reports contourites and enhanced MOW contour circulation controlled by millennial-scale variability back to $140 \mathrm{kyr}$ (Bahr et al., 2014), validated by the consistent pattern of upper and lower-MOW contour-currents. At our two sites, silty-contourites are clearly identified by $\mathrm{Zr} / \mathrm{Al}$ as in Bahr et al. (2014), where the highest values are associated with deglacial silty-contourites I6 and M5, I5, M4 and M3, and to a lesser extent Holocene silty-contourites I2, M1 and I0. In our study, moreover, $\mathrm{Zr} / \mathrm{Al}$ is coherent with current sorting (GC01, TG2) and current speed (GC01) (Suppl. Fig. S6A, C, B).

The duration of deposition of what we identified as fast-contourite events is estimated between 200 and 2200 years in the Faro Drift, and between 100 and 1000 years in the Moroccan Drift (Table 2). The duration is irrespective of deglacial or Holocene periods. Hence, we can infer that silty-contourites deposition takes place over short periods and occurs during millennial oceanographic/climatic cold events.

The case of I6 in the Faro Drift illustrated here with high resolution (Fig. 8) is particularly remarkable, because it is timed at the second phase (Naughton et al., 2009) of abrupt event HS1. It has been suggested that HS1, as HS2 and HS4 events, had 2 phases in mid-North Atlantic: the first less cold (less IRD) and wet on land and the second cool (more IRD) and dry, due to a southern $\left(36^{\circ} \mathrm{N}\right)$ or northern $\left(42^{\circ} \mathrm{N}\right)$ migration of the Intertropical Convergence Zone (ITCZ) (Naughton et al., 2009). The doublephase in Heinrich Stadials appears also in the GoC in the lower-MOW of MD99-2339 (Voelker et al., 2006). Further, the HS1 recorded at GC01 clearly resolves the two different phases, with the transition between the two marked by a peak of maximum \% $N$. pachyderma, coinciding with onset of the silty-contourite (increase in $\overline{S S}$ ) (Fig. 8AC). This in turn validates the hypothesis of enhanced sedimentary processes (intensification of contourite currents in this case) during transitions of abrupt climatic changes (Lebreiro et al., 2009; Lebreiro, 2010; Voelker et al., 2006).

In order to understand the processes behind the MOW export through the Straits of Gibraltar during HS1, we compared the evolution of isotopic signals of planktonic and benthic foraminifera on both sides of Gibraltar considering MD01-2472 from $501 \mathrm{~m}$ in the Corsica Trough (Toucanne et al., 2012) and MD99-2343 from $2400 \mathrm{~m}$ in the 
Menorca Drift (Frigola et al., 2008; Sierro et al., 2005), and GC01 from $550 \mathrm{~m}$ in the Faro Drift (Fig. 8). The Mediterranean cores (MD01-2472 and MD99-2343) are characterised by quite similar O isotopic signal and trend during HS1, compared to a much ligher GoC (GC01) (Fig. 8 A). However, the timing of maximum surface cooling (higher \% N. pachyderma) is coincidental in Menorca and the GoC (Fig. 8C). The following sequence of processes is observed in the Mediterranean and/or GoC during HS1 (Fig. 8): 1) continuous gradual depletion of $\delta^{18} \mathrm{O}$ of $G$. bulloides, 2) decreasing trend in $\delta^{13} \mathrm{C}$ of $C$. pachyderma, heavier for the WMDW, and more similar and lighter signal for the intermediate water masses but, 3) simultaneous peak of maximum $\% \mathrm{~N}$. pachyderma at $17.2 \mathrm{ka}$, followed by 4) deposition of I6 in the northern $\mathrm{GoC} \sim 1 \mathrm{ka}$ later (peak of $\overline{S S}$ at $16.8 \mathrm{ka}$ ) in the GoC, 5) short and abrupt interval of extremely low values of $\delta^{13} \mathrm{C} C$. pachyderma detected in WMDW in Menorca at 16-15.7 kyr (Frigola et al., 2008; Sierro et al., 2005), and then 6) abrupt increase in SST in the GoC (Fig. 8A, B, C, D, E). This extreme event at the end of the second phase of HS1 is not identified neither in the Mediterranean intermediate waters nor in the Faro Drift (Fig. 8D). Sierro et al. (2005) suggested that when cold Atlantic surface waters entered the Mediterranean, WMDW formation slowed-down gradually to extreme $\delta^{13} \mathrm{C}$ values (minimum $\delta^{13} \mathrm{C}$ ) until WMDW production collapsed at the end of the Heinrich stadial. Integration of their results with ours would imply, instead, that slow-down of Mediterranean dense waters, initiated in the Gulf of Lions during the LGM was not reflected in the GoC until the onset of HS1 (Fig. 8B). The presence of cold Atlantic Waters in Menorca (slightly depleted planktonic $\delta^{18} \mathrm{O}$ and increasing \% Nq.pachyderma) since $18.5 \mathrm{ka}$, sustained the gradual decrease in Mediterranean deep overturning for $1.5 \mathrm{ka}$ (Fig. 8A, C, B). In the GoC, MOW remained sluggish $(\overline{S S})$ and unaffected during the LGM and first half of HS1 (Fig. 8D), although surface temperatures cooled down (Fig. 8E). At $17.2 \mathrm{ka}$, in the middle of HS1, SST cooled to its minimum temperature in both the Mediterranean and the GoG (Fig. 8E, C). In the deep Mediterranean (WMDW), the collapse of overturning in the basin only appears to be reached later (16-15.7 kyr; Sierro et al., 2005) (Fig. 8B). In contrast, the MOW in the GoC speeded up during the second half of HS1, just after the maximum volume of Atlantic Waters entered the Mediterranean (Fig. 8D). While WMDW slowed down gradually over HS1, LIW ventilation increased moderately during the first half of HS1 as did MOW during the second half (Fig. 8B) Given the decoupling between Mediterranean deep and intermediate waters, we would have to assume that 1) Atlantic Waters affected mainly the MIW rather than WMDW, and 2) Mediterranean Intermediate and Deep waters are decoupled in the process of forcing MOW export. The deposition of silty-contourite I6 (maximum $\overline{S S}$ in Fig. 8D), reinforces the idea of a substantial amount of salt injected from the Mediterranean into the GoC through the Straits of Gibraltar (Rogerson et al., 2006; Voelker et al., 2006) carried over by the upper-MOW. Our records (GC01) further corroborate the hypothesis that the cooccurrence of a collapse of WMDW formation (Fig. 8B) and an abrupt increase in SSTs in the $\mathrm{GoC}$ by $10^{\circ} \mathrm{C}$ in 1000 years, would have triggered the following interstadial (B/A in Fig. 8E). Immediately after the abrupt collapse of WMDW, SST reached $16.7^{\circ} \mathrm{C}$ (Fig. $8 \mathrm{E})$.

The occurrence of this series of events demonstrates the link between ocean processes in the Mediterranean Sea and in the GoC. The Mediterranean response to Atlantic surface freshening through the Straits of Gibraltar seems to result in the enhancement of MIW, which in turn forces the MOW into the GoC (Rogerson et al., 2012).

To summarize, the similarity of benthic $\mathrm{C}$ and $\mathrm{O}$ isotopic trends at millennial time scales for intermediate waters (upper-MOW GC01 in the GoC, LIW MD01-2472 in 
Corsica Trough) and deep waters (WMDW MD99-2343 in Menorca), might not be caused by the direct forcing of deep WMDW formation in the western Mediterranean during arid and cold stadials (Cacho et al., 2001, 2006; Moreno et al., 2005; RodrigoGámiz et al., 2011; Rogerson et al., 2006; Voelker et al., 2006), but by MIW forcing of MOW. Deep and intermediate waters might be showing correlation but not causation. During deglacial times, fast contourites I6 (HS1) and M5, I5, M4, M3 (YD) are deposited under the influence of the enhanced upper-MOW contour-current at $550 \mathrm{~m}$ towards opposite $\mathrm{N}$ and $\mathrm{S}$ sides of the GoC. The $\overline{S S}$ confirms the intense upper-MOW flow at millennial time scales. Notably, our results resolve in greater detail the process of salt injection by contour-currents at different speeds in the northern and/or southern margin of the GoC. Interruption of salt injection into the $\mathrm{GoC}$ (contour-current) appears to correlate with the slow-down of WDMW formation and intensification of MIW, forcing abrupt increase in surface temperatures in the Atlantic (Fig. 8A, D, E). This would have then promoted resumption of intermediate and deep overturning in the North Atlantic (Gherardi et al., 2005; McManus et al., 2004; Rogerson et al., 2006; Voelker et al., 2006) during the onset of the B/A (millennial scale) or the Holocene (orbital scale). A critical balance is expected in the interplay between freshwater input from Atlantic waters and salt export from the Mediterranean at intermediate depths. In sedimentary facies, the product has been the sequence of slow- and fast- contourites building contouritic drifts depositing muddy- and silty- contourites in the $\mathrm{N}$ and $\mathrm{S}$ of the GoC.

\section{CONCLUSIONS}

Muddy- and silty-contourites in a drift are likely generated by the interaction of processes with distinct compositional and dynamical conditions. The upper-MOW export to the $\mathrm{GoC}$ is dominant during the Holocene compared to the Last Glacial, according to $\overline{S S}$ variation on interglacial-glacial scales. However, superimposed on the orbital variability, the contouritic sedimentation process responds to millennial climate variability. Stronger contour-currents of 1 ka-duration on average prevail during shortlived abrupt global cold events, mainly HS1 and YD, but exist also as specific episodes in the Holocene.

Contourites on the northern and southern margins of the GoC do not change significantly in their benthic $\delta^{13} \mathrm{C}$ isotopic composition to invoke different origins for the contour-currents. The upper-MOW was therefore not only confined close to the northern $\mathrm{GoC}$, but it also supplied water to the southern GoC along the Moroccan midslope. The proportion of the upper-MOW likely became reduced and mixed with Atlantic waters along the Moroccan margin, entrained by northern NACW and/or southern AAIW. Flow-patterns from present-day numerical simulations in the GoC, together with CTDs in the southern margin, seem to support the hypothesis of the existence of a southward branch of Mediterranean Outflow, which could have contributed to the deposition of Moroccan contourite systems $\left(35^{\circ} \mathrm{N} ; 7^{\circ} \mathrm{W}\right)$ since the last deglaciation.

The enhanced salt injection into the GoC through the MOW- southern and northern branches (clearly demonstrated by deposition of silty-contourite I6 during HS1), is the result of Atlantic-Mediterranean exchange by surface freshening, MIW intensification, sudden collapse of WMDW in the western Mediterranean, ultimately causing SST $\left(10^{\circ} \mathrm{C} / 1 \mathrm{ka}\right)$ to skyrocket into the next interstadial $(\mathrm{B} / \mathrm{A})$. 


\section{Acknowledgements}

This work was done within the framework of the Contouriber coordinated project Contourite depositional Systems generated by Mediterranean water masses around Iberia: evolution and global implication, subproject CTM2008-06399-CO4-02/MAR, supported by the Spanish Ministerio de Ciencia e Innovación. Core GC-01A-PC\&TC was collected during cruise CONTOURIBER-1, 2010, and core MVSEIS08_TG-2 during cruise MVSEIS2008 (Euromargins project 01-LEC-EMA24F/ CYCIT REN2002-11669-E/MAR).

This study uses four CTD cast-data, collected onboard the RRS Charles Darwin, cruise CD171, in 2005, provided by the British Oceanographic Data Centre and the Natural Environment Research Council. The numerical simulations were carried out at the National Oceanography Centre Southampton by the Marine Systems Modelling group.

Esperanza Pellicer washed a number of samples for $\mathrm{O}$ and $\mathrm{C}$ oxygen isotope analysis, as part of her practical credits for the Geology degree in the University Complutense of Madrid. Jaime Frigola is acknowledged for support during acquisition and interpretation of XRF data sets in the University of Barcelona. Antje Voelker critically reviewed an earlier version of this manuscript. Mike Rogerson and an anonymous reviewer greatly improved this manuscript with constructive contributions.

\section{FIGURE CAPTIONS}

Figure 1. Location of contourite drift sites in the N and S of the Gulf of Cadiz: GC01A-PC $\left(36^{\circ} 42.6257^{\wedge} \mathrm{N} ; 7^{\circ} 44.7173^{\prime} \mathrm{W} ; 566 \mathrm{~m}\right.$; cored in preparation for IODP site U1386) and MVSEIS08_TG-2 (34 $\left.58.28^{\circ} \mathrm{N} ; 6^{\circ} 50.47^{`} \mathrm{~W} ; 530 \mathrm{~m}\right)$, referred in text as GC01 and TG2, respectively (A). Reference core MD99-2339 $\left(35.88^{\circ} \mathrm{N}, 7.53^{\circ} \mathrm{W}, 1170\right.$ $\mathrm{m})$ (Voelker et al., 2006). Note the presence of upper- and lower- MOW in the diagrams of Temperature/Salinity (B) and Salinity/Depth (C) across the red line transect on the southern Moroccan margin, from compilation of stations 674299 (550 m), 674287 (995 $\mathrm{m}), 674275(1485 \mathrm{~m})$ and $674263(2295 \mathrm{~m})$, available from the British Oceanographic Data Centre (BODC) of the Natural Environment Research Council, United Kingdom. ENACW (Eastern North Atlantic Central Water), AAIW (Antarctic Intermediate Water), MOW (Mediterranean Outflow Water), and ENADW (Eastern North Atlantic Deep Water).

Figure 2. Suggested hypotheses for the occurrence of contourites along the Moroccan margin.

Figure 3. Age model for cores GC-01A-TC/PC and MVSEIS08_TG-2, where fastcontourites (orange stripes) are marked by high $\mathrm{Zr} / \mathrm{Al}$. Correlation of $\delta^{18} \mathrm{O}$ of planktonic foraminifera in GC01 (TC for trigger and PC for piston core) (A) and TG2 (B) with biomarkers-SST from core MD01-2444 (Martrat et al., 2007) on the Portuguese margin. Age-depth diagrams with probability distributions and sedimentation rates of GC01 and TG2 (C and D). I $i$ and Mi stand for Iberia and Morocco silty-contourites (orange stripes; see text for identification of silty-contourites); YD is Younger Dryas and $\mathrm{HS} i$ is Heinrich Stadial event $i$ (blue stripes). 
1000 Figure 4. Relationship between XRF-Zr/Al composition, and sortable silt (contourcurrent strength) and SS\% $(\%(10-63 \mu \mathrm{m}) /<63 \mu \mathrm{m})$ for the Iberian GC01 (A) and Moroccan TG2 (B) sites with $\delta^{13} \mathrm{C}$ of benthic foraminifera Cibicides pachyderma.

Vertical stripes denote fast-contourites (orange) and cold climate events Heinrich Stadial 1 (HS1) and Younger Dryas (YD) (blue). I $i$ and M $i$ denote Iberian and Moroccan silty-contourites, respectively.

Figure 5. Polar, subpolar and subtropical climate assemblages of planktonic foraminifera in percentage (see text for assemblages of species) (A). Sea Surface Temperatures (SST) (winter) based on Simmax 28 for the GoC records (this study) and alkenones for MD95-2043 (Cacho et al., 2001) (B). Percentage of G.scitula as indicator of cold surface water and the Azores Front (Rogerson et al., 2004) (C). Comparison of $\delta \mathrm{O}^{18}$ of planktonic foraminifera (G.bulloides) between the GoC (this study, GC01 and TG2) and the western Mediterranean (Alboran Sea, site MD95-2043; 36 8.6'N, $2^{\circ}$ $37.3^{\prime} \mathrm{W}, 1841 \mathrm{~m}$; Cacho et al., 2001) (D); note the difference of 0.75-1.0 \% PDB shown between the 2 records. Symbols: red bold circles for GC01 and purple open circles for TG2. In B) triangles with numbers identify fast-contourites (red for GC01 and purple for TG2).

Figure 6. Comparison of $\delta^{13} \mathrm{C}$ of benthic foraminifera Cibicides pachyderma between upper-MOW in the Moroccan (TG2, purple thick bold line and open circles) and in the Iberian (GC01, red thick bold line) sites (this study). Further comparison of these with glacial and deglacial lower-MOW (MD99-2339, thin bold line; Voelker et al., 2006) difference shaded in purple - at the GoC and MD95-2043 (dotted line; Cacho et al., 2006) at the western Mediterranean Sea (A).

Below, $\delta^{18} \mathrm{O}$ of Cibicides pachyderma of TG2 and GC01 (this study) bathed by the upper-MOW, compared to MD99-2339 in the lower-MOW (Voelker et al., 2006) (B).

Figure 7. Salinity (shading) and current velocity (arrows) patterns outside of the Straits of Gibraltar from a high-resolution ocean model at $857 \mathrm{~m}$ in two different seasons, autumn (A) and winter (B). Meridional salinity cross-section in the Gulf of Cadiz at $\sim 7^{\circ} \mathrm{W}$ for the winter months (black line located in panel B) (C). All data represents a 2000-2007 climatology.

Figure 8. Zoom of silty-contourite I6 (Iberian margin) occurring during Heinrich Stadial event 1 (HS1). Comparison of oceanographic changes between the GoC (core GC01, red bold circles) and the western Mediterranean Sea (Corsica Trough, core MD01-2472, Toucanne et al. 2012 in blue bold squares; Menorca Drift, core MD992343 , Sierro et al. 2005, in black open diamonds), based on $\delta \mathrm{O}^{18}$ of planktonic foraminifera G. bulloides (A), $\delta^{13} \mathrm{C}$ of benthic foraminifera (Cibicides pachyderma for GC01 and Uvigerina spp. for MD01-2472) (B), \% of polar planktonic foraminifera $N$. pachyderma (C), $\overline{S S}$-sortable silt mean (D), and foraminifera-Sea Surface Temperature (winter) (E). Blue vertical bar outlines HS1.

Table 1. Dates 14C AMS.

Table 2. Duration of silty-contourites and millennial events.

\section{REFERENCES}


Álvarez, M., Pérez, F.F., Bryden, H., Ríos, A.F., 2004. Physical and biogeochemical transports structure in the North Atlantic subpolar gyre. J. Geophys. Res. 109, C03027. doi:10.1029/2003JC002015.

Álvarez, M., Pérez, F.F., Shoosmith, D.R., Bryden, H.L., 2005. Unaccounted role of Mediterranean Water in the drawdown of anthropogenic carbon. J. Geophys. Res. 110, C09S03.doi:10.1029/2004JC002633.

Ámbar, I., 1983. A shallow core of Mediterranean water off western Portugal. Deep-Sea Res. 30 (6A), 677-680, doi: 10.1016/0198-0149(83)90045-6.

Ámbar, I., Howe, M.R., 1979. Observations of the Mediterranean Outflow: Deep-Sea Res. 26A I: Mixing in the Mediterranean outflow, 535-554, and II: The deep circulation in the vicinity of the Gulf of Cadiz, 555-568, doi:10.1016/0198-0149(79)90096-7.

Ámbar, I., Armi, L., Bower, A., Ferreira, T., 1999. Some aspects of time variability of the Mediterranean Water off south Portugal. Deep-Sea Res. I, 46, 1109-1136. doi:10.1016/j.jmarsys.2007.07.003

Ámbar, I., Serra, N., Neves, F., Ferreira, T., 2008. Observations of the Mediterranean Undercurrent and eddies in the Gulf of Cadiz during 2001. J. Marine Syst. 71, 195-220, doi:10.1016/j.jmarsys.2007.07.003

Antonov, J.I., Locarnini, R.A., Boyer, T.P., Mishonov, A.V., Garcia, H.E., 2006. World Ocean Atlas 2005: Salinity. In: Levitus, S. (Ed.), NOAA Atlas NESDIS, 62 (2), U.S. Government Printing Office, Washington, $182 \mathrm{pp}$.

Arhan, M., King, B., 1995. Lateral mixing of the Mediterranean Water in the Eastern North Atlantic. J. Mar. Res. 53 (9), 865-895, doi:10.1357/0022240953212990.

Armi, L.D., Hebert, D., Oakey, N., Price, J F., Richardson, P.L., Rossby, H.T., Ruddick, B., 1989. Two years in the life of a Mediterranean salt lens, J. Phys. Ocenogr. 19, 354-370.

Bahr, A., Jiménez-Espejo, F.J., Kolasinac, N., Grunert, P., Hernández-Molina, F.J., Röhl, U., Voelker, A.H.L., Escutia, C., Stow, D.A.V., Hodell, D., Alvarez-Zarikian C.A., 2014. Deciphering bottom current velocity and paleoclimate signals from contourite deposits in the Gulf of Cadiz during the last 140 kyr: An inorganic geochemical approach, Geochem. Geophy. Geosy. 15, doi:10.1002/2014GC005356.

Bé, A.W.H., Tolderlund, D.S., 1971. Distribution and ecology of living planktonic foraminifera in surface waters of the Atlantic and Indian Oceans. In: Funnel, B.M. and Riedel, W.R. (Eds.), The Micropaleontology of Oceans, London, Cambridge University Press, pp. 105-149.

Bethoux, J.P., 1979. Budgets of the Mediterranean Sea. Their dependence on the local climate and on the characteristics of the Atlantic waters. Oceanol. Acta, 2, 157-163.

Blaker, A.T., Hirschi, J.J.-M., McCarthy, G., Sinha, B., Taws, S., Marsh, R., Coward, A., de Cuevas, B., 2014. Historical analogues of the recent extreme minima observed in the Atlantic meridional overturning circulation in the Atlantic meridional overturning circulation at $26^{\circ} \mathrm{N}$. Clim. Dynam.26, 1-17, doi: 10.1007/s00382-014-2274-6.

Bond, G., Broecker, W., Johnsen, S., McManus, J., Labeyrie, L., Jouzel, J., Bonani, G., 1993. Correlations between climate records from North Atlantic sediments and Greenland ice. Nature 365, 143-147, doi: 10.1038/365143a0.

Borenäs, K.M., Wahlin, A.K., Ámbar, I., Serra, N., 2002. The Mediterranean outflow splitting-a comparison between theoretical models and CANIGO data. Deep-Sea Res. Pt II 49, $4195-$ 4205, doi: 10.1016/S0967-0645(02)00150-9.

Broeker, W.S., 1991. The great ocean conveyor. Oceanography 4(2), 79-89, doi.org/10.5670/oceanog.1991.07.

Cabeçadas, G., Brogueira, M.J., Gonçalves, C., 2002. The chemistry of Mediterranean outflow and its interactions with surroundings waters. Deep-Sea Res. Pt II 49, 4263-4270, doi: 10.1016/S0967-0645(02)00154-6.

Cacho, I., Grimalt, J.O., Canals, M., Sbaffi, L., Shackleton, N.J., Schönfeld, J., Zahn, R., 2001. Variability of the western Mediterranean sea surface temperature during the last 30,000 years and its connection with the northern hemisphere climatic changes. Paleoceanography 16 (1), 40-52, doi: 10.1029/2000PA000502. 
Cacho, I., Shackleton, N., Elderfield, H., Sierro, F.J., Grimalt, J.O., 2006. Glacial rapid variability in deep-water temperature and $\delta 180$ from the Western Mediterranean Sea. Quaternary Sci. Rev. 25 (23-24), 3294-3311, doi: 10.1016/j.quascirev.2006.10.00.

Carton, X., Cherubin, L., Paillet, J., Morel, Y., Serpette, A., Le Cann, B., 2002. Meddy coupling with a deep cyclone in the Gulf of Cadiz. J. Marine Syst. 32, 13-42, doi:10.1016/S09247963(02)00028-3.

Carton, X., Daniault, N., Alves, J., Cherubin, L., Ámbar, I., 2010. Meddy dynamics and interaction with neighboring eddies southwest of Portugal: Observations and modeling. J. Geophys. Res. 115, C06017. doi:10.1029/2009JC005646.

Casas, D., Medialdea, T., Somoza, L., Leon, R., Ercilla, G., Team, M.V.S.E.I.S., 2010. Bottom current features in the slope of the Atlantic Moroccan margin. In: Hernández-Molina, F.J., Stow, D.A.V., Llave, E., Rebesco, M., Ercilla, G., Van Rooij, D., Mena, A., Vásquez, J.T., Voleker, A. (Eds.), Deep-water Circulation: Processes \& Products, Sociedad Geológica de España, Extended Abstract, International Congress, Baiona (Vigo, Spain), 16-18 June 2010. Geo-Temas 11, 29-30.

Curry, W.B. and Oppo, D.W., 2005. Glacial water mass geometry and the distribution of $\delta^{13} \mathrm{C}$ of $\Sigma \mathrm{CO}_{2}$ I the western Atlantic Ocean. Paleoceanography, 20, doi:10.1029/2004PA001021.

de Jonge, C., 2010. A multi-proxy approach to the paleoceanographic variability within the last glacial cycle offshore Morocco. Master of Sciences, University of Gent, $25 \mathrm{pp}$.

Deshayes, J., Treguier, A.-M., Barnier, B., Lecointre, A., Sommer, J.L., Molines, J.-M., Penduff, T., Bourdallé-Badie, R., Drillet, Y., Garric, G., Benshila, R., Madec, G., Biastoch, A., Böning, C.W., Scheinert, M., Coward, A.C., Hirschi, J.J.-M., 2013. Oceanic hindcast simulations at high resolution suggest that the Atlantic MOC is bi-stable. Geophys. Res. Lett. 40 (12), 3069-3073, doi:10.1002/grl.50534.

Drillet, Y., Bourdallé-Badie, R., Siefridt, L., Le Provost, C., 2005. Meddies in the Mercator North Atlantic and Mediterranean Sea eddy-resolving model. J. Geophys. Res.-Oceans, 110 (C3), 1978-2012, doi:10.1029/2003JC002170.

Ducassou, E., Hassan, R., Hanquiez, V., Duprat, J., Gonthier, E., Mulder, T., Toucanne, S., 2014. Biostratigraphy of the Holocene and of the main cold events of the Late Quaternary in the Gulf of Cadiz. In: R.Rocha, J. Pais, J.C. Kullberg and S. Finney (Eds.), STRATI 2013, Springer Geology, pp. 1297-1301.

Duchez, A., Frajka-Williams, E., Castro, N., Hirschi, J.J.-M., Coward, A., 2014. Seasonal to interannual variability in density around the Canary Islands and their influence on the Atlantic meridional overturning circulation at $26^{\circ} \mathrm{N}$. J. Geophys. Res.-Oceans 119 (3), 1843-1860, doi:10.1002/2013JC009416.

Fairbanks, R.G., 1989. A 17,000-year glacio-eustatic sea level record: influence of glacial melting rates on the Younger Dryas event and deep-ocean circulation. Nature, 342, 637641, doi:10.1038/342637a0.

Faugères, J.-C., Gonthier, E., Stow, D.A.V., 1984. Contourite drift molded by deep Mediterranean Outflow. Geology 12, 296-300.

Faugères, J.-C., Gonthier, E., Peypouquet, J.-P., Pujol, Vergnaud-Grazzini, C., 1986. Distribution et variations des courants de fond sur la ride de Faro (golfe de Cadix), témoins des modifications des échanges Mediterranée-Atlantique au Quaternaire récent. Bull.Soc.Geol.France, II, 3, 423-432.

Faugères, J.-C., Gonthier, E., Monteiro, H., Vergnaud-Grazzini, C., 1994. Sedimenatry records of deep contour currents: an example, the Mediterranean Outflow in the late Quaternary. Comun. Inst.Geol. e Mineiro, 80, 71-88.

Faugères, J.-C., Cremer, M., Monteiro H., Gaspar, L., 1985. Growth pattern processes of the Faro Drift (South Portugal). Bull. Inst. Geol. Bass. Aquitaine 37, 229-258.

Foubert, A., Depreiter, D., Beck, T., Maignien, L., Pannemans, B., Frank, N., Blamart, D., Henriet, J.-P., 2008. Carbonate mounds in a mud volcano province off north-west Morocco: Key to processes and controls. Mar. Geol. 248, 74-96. doi:10.1016/j.margeo.2007.10.012. 
Frigola, J., Moreno, A. Cacho, I., Canals, M., Sierro, F.J., Flores, J.A., Grimalt, J.O, 2008. Evidence of abrupt changes in Western Mediterranean Deep Water circulation during the last 50 kyr: a high-resolution marine record from the Balearic Sea. Quatern. Int. 181, 88104, doi:10.1016/j.quaint.2007.06.016.

García Lafuente, J., Sánchez Román, A., Díaz del Río, G., Sannino, G., Sánchez Garrido, J.C., 2007. Recent observations of seasonal variability of the Mediterranean outflow in the Strait of Gibraltar. J. Geophys. Res., 112, C10005, doi:10.1029/2006JC003992.

Gherardi, J.-M., Labeyrie, L., McManus, J.F., Francois, R., Skinner, L.C., Cortijo, E., 2005. Evidence from the northeastern Atlantic basin for variability in the rate of the meridional overturning circulation through the last deglaciation. Earth Planet. Sci. Lett. 240, 710 -723, doi:10.1016/j.eps1.2005.09.061.

Gonthier, E.G., Faugères, J.-C., Stow, D.A.V., 1984. Contourite facies of the Faro Drift, Gulf of Cadiz. In: Stow, D.A.V. and Piper, D.J. (Eds.), Fine-Grained Sediments: Deep-Water Processes and Facies, Vol. 15, Geol. Soc. Spec. Publ., Oxford, pp. 275-292.

Hemleben, Ch., Spindler, M., Anderson, O.R., 1989. Modern planktonic foraminifera. Springer-Verlag, New York, 363 pp.

Hernández-Guerra, A., Fraile-Nuez, E., Borges, R., López-Laatzen, F., Vélez-Belchí, P., Parrilla, G., Müller, T.J., 2003. Transport variability in the Lanzarote passage (Eastern boundary current of the North Atlantic subtropical Gyre). Deep-Sea Res. I, 50, 189-200.

Hernández-Molina, F.J., 2011. Informe Científico Campaña Oceanográfica CONTOURIBER-1, B/O Sarmiento de Gamboa, 17 Septiembre a 14 de Octubre de 2010, Proyecto de Investigación CTM2008-06399-C04/MAR, Universidad de Vigo, España.

Hernández-Molina, F.J., Llave, E., Somoza, L., Fernandez Puga, M.C., Maestro, A., León, R., Barnolas, A., Medialdea, T., García, M., Vázquez, J.T., Díaz del Río, V., Fernandez-Salas, L.M., Lobo, F., Alveirinho Dias, J.M., Rodero, J., Gardner, 2003. Looking for clues to paleoceanographic imprints: a diagnosis of the Gulf of Cadiz contourite depositional systems. Geology 31 (1), 19-22, dx.doi.org/10.1130/00917613(2003)031<0019:LFCTPI>2.0.CO;2.

Hernández-Molina, F.J., Llave, E., Stow, D.A.V., García, M., Somoza, L., Vázquez, J.T., Lobo, F.J., Maestro, A., Díaz del Río, V., León, R., Medialdea, T., Gardner J., 2006. The contourite depositional system of the Gulf of Cadiz: A sedimentary model related to the bottom current activity of the Mediterranean outflow water and its interaction with the continental margin. Deep-Sea Res. Pt II 53, 1420-1463, doi:10.1016/j.dsr2.2006.04.016.

Hernández-Molina, F. J., Stow, D. A. V., Alvarez Zarikian, C.A., Exp. IODP 339 Scientists, 2013. IODP Expedition 339 in the Gulf of Cadiz and off West Iberia: decoding the environmental significance of the Mediterranean outflow water and its global influence, Scientific Drillling 16, 1-11, doi:10.5194/sd-16-1-2013.

Hernández-Molina, F.J., Llave, E., Preu, B., Ercilla, G., Fontan, A., Bruno, M., Serra, N., Gomiz, J.J., Brackenridge, R.E., Sierro, F.J., Stow, D.A.V., García, M., Juan, C., Sandoval, N., Arnaiz, A., 2014. Contourite processes associated with the Mediterranean Outflow Water after its exit from the Strait of Gibraltar: Global and conceptual implications. Geology 42, 227-230, doi:10.1130/G35083.1.

Hughen, K.A., Baillie, M.G.L., Bard, E., Beck, J.W., Bertrand, C.J.H., Blackwell, P.G., Buck, C.E., Burr, G.S., Cutler, K.B., Damon, P.E., Edwards, R.L., Fairbanks, R.G., Friedrich, M., Guilderson, T.P., Kromer, B., McCormac, G., Manning, S., Ramsey, C.B., Reimer, P.J., Reimer, R.W., Remmele, S., Southon, J.R., Stuiver, M., Talamo, S., Taylor, F.W., van der Plicht, J., Weyhenmeyer, C.E., 2004. Marine04 Marine Radiocarbon Age calibration, 0-26 cal kyr BP. Radiocarbon 46, 1059 -1086, doi:10.1017/S0033822200033002.

Iorga, M.C., Lozier, M.S., 1999. Signatures of the Mediterranean outflow from a North Atlantic climatology: 1. Salinity and density fields. J. Geophys. Res.-Oceans 104, 25985-926009. 
Jenkins, W.J., Smethie Jr., W.M., Boyle, E.A., Cutter, G.A., 2015. Water mass analysis for the U.S. GEOTRACES (GA03) North Atlantic sections, Deep-Sea Res. Pt II, 116 (6-20), doi:10.1016/j.dsr2.2014.11.018.

Kaboth, S., Bahr, A., Reichart, G.-J., Jacobs, B., Lourens, L., 2016. New insights into upper MOW variability over the klast $150 \mathrm{kyr}$ IODP 339 Site U1386 in the Gulf of Cadiz. Mar. Geol. 377, 136-145, doi:10.1016/j.margeo.2015.08.014.

Kinder, T.H., Parrilla, G., 1987. Yes, some of the Mediterranean Outflow does come from great depth. J. Geophys. Res. 92(C3), 2901-2906.

Knoll, M., Hernández-Guerra, A., Lenz, B., López Laatzen, F., Machín, F., Muller, T.J., Siedler, G., 2002. The Eastern Boundary Current system between the Canary Islands and the African Coast, Deep-Sea Res. II 49, 3427-3440.

Kucera, M., 2007. Planktonic foraminifera as tracers of past oceanic environments. In: HillaireMarcel, C. and de Vernal, A. (Eds.), Proxies in Late Cenozoic Paleoceanography (Pt. 2): Biological tracers and biomarkers, Elsevier, Amsterdam, pp. 213-262, ISSN 1572-5480, doi: 10.1016/S1572-5480(07)01011-1.

Lebreiro, S. M., 2010. Circum-Iberia turbidites and contourites: enhancement of processes by AMOC millennial-scale climate changes, In: Hernández-Molina, F.J., Stow, D.A.V., Llave, E., Rebesco, M., Ercilla, G., Van Rooij, D., Mena, A., Vásquez, J.T., Voelker, A. (Eds.), Deep-water Circulation: Processes \& Products, Sociedad Geológica de España. Extended Abstract, International Congress, Baiona (Vigo, Spain), 16-18 June 2010. Geo-Temas 11, 93-94.

Lebreiro, S.M., Voelker, A.H.L., Vizcaino, A., Abrantes, F.G., Alt-Epping, U., Jung, S., Thouveny, N., Gràcia, E., 2009. Sediment instability on the Portuguese continental margin under abrupt glacial climate changes (last 60 kyr). Quaternary Sci. Rev. 28, 3211-3223, doi:10.1016/j.quascirev.2009.08.007. doi:10.1594/PANGAEA.733461.

Llave, E., Hernández-Molina, F.J., Somoza, L., Díaz-del-Río, V., Stow, D.A.V., Maestro, A., Alveirinho Dias, J.M., 2001. Seismic stacking pattern of the Faro-Albufeira contourite system (Gulf of Cadiz): a Quaternary record of paleoceanographic and tectonic influences. Marine Geophys. Res. 22, 487-508, doi:10.1023/A:1016355801344.

Llave, E., Schönfeld, J., Hernández-Molina, F.J., Mulder, T., Somoza, L., Díaz del Río, V., 2006. High-resolution stratigraphy of the Mediterranean outflow Contourite system in the Gulf of Cadiz during the Late Pleistocene: the impact of Heinrich events. Mar. Geol. 227, 241-262, doi:10.1016/j.margeo.2005.11.015.

Llinás, O., Rueda, M.J., Pérez Marrero, J., Pérez-Martell, E., Santana, R., Villagarcía, M.G., Cianca, A., Godoy, J., Maroto, L., 2002. Variability of the Antarctic intermediate waters in the Northern Canary Box. Deep-Sea Res. Pt II 49, 3441-3453, doi:10.1016/S09670645(02)00090-5.

Locarnini, R.A., Mishonov, A.V., Antonov, J.I., Boyer, T.P., Garcia, H.E., 2006. World Ocean Atlas 2005: Salinity. In: Levitus, S. (Ed.), NOAA Atlas NESDIS 61 (1), U.S. Government Printing Office, Washington, $182 \mathrm{pp}$.

Loeblich, A. R., Tappan, H., 1964. Sarcodina-chiefly "Thecamoebians" and Foraminiferida. In: Moore, R.C. (Ed.), Treatise on Invertebrate Paleontology, Part C, Protista 2 (2 volumes), University of Kansas Press, 900 pp.

Louarn, E., Morin, P., 2011. Antarctic Intermediate Water influence on Mediterranean Sea Water outflow. Deep-Sea Res. Pt I 58, 932-942, doi:10.1016/j.dsr.2011.05.009.

Machín, F., Pelegrí, J.L., 2016. Interaction of Mediterranean Water lenses with Antarctic Intermediate Water off Northwest Africa. Scientia Mar, doi:10.3989/scimar.04289.06A.

Machín, F., Pelegrí, J.L., Marrero-Díaz, A., Láiz, I., Ratsimandresy, A.W., 2006. Near-surface circulation in the southern Gulf of Cádiz. Deep-Sea Res. Pt II, 53, 1161-1181, doi:10.1016/j.dsr2.2006.04.001.

Machín, F., Pelegrí, J.L., Fraile-Nuez, E., Vélez-Belchí, P., López-Laatzen, F., HernándezGuerra, A., 2010. Seasonal Flow Reversals of Intermediate Waters in the Canary Current System East of the Canary Islands. J. Phys. Ocenogr.40, 1902-1909, doi:10.1175/2010JPO4320.1. 
Madec, G., 2008. NEMO ocean engine. Note du Pole de modélisation, Institut Pierre Simon Laplace (IPSL), France.

Martrat, B. Grimalt, J.O., Shackleton, N.J., Abreu, L.de, Hutterli, M.A., Stocker, T.F., 2007. Four climate cycles of recurring deep and surface water destabilizations on the Iberian Margin, Science 317 (5837), 502-507, doi:10.1126/science.1139994. doi:10.1594/PANGAEA.771891.

Marzocchi, A., Hirschi, J.J.-M, Holliday, N.P., Cunningham, S.A., Blaker, A.T., Coward, A.C., 2015. The North Atlantic subpolar circulation in an eddy-resolving global ocean model. J. Marine Syst. 142, 126-143, doi:10.1016/j.jmarsys.2014.10.007.

McCave, I.N., 2008. Size sorting during transport and deposition of fine sediments: sortable silt and flow speed. In: Rebesco, M. and Camerlenghi, A. (Eds), Contourites, Elsevier, pp. 121142.

McCave, I.N., Hall, I.R., 2006. Size sorting in marine muds: processes, pitfalls, and prospects for paleoflow-speed proxies. Geochem. Geophy. Geosy. 7 (10) doi:10.1029/2006GC001284.

McCave, I.N., Manighetti, B. and Robinson, S.G., 1995. Sortable silt and fine sediment size/composition slicing: parameters for paleocurrent speed and paleoceanography. Paleoceanography 10(3), 593-610, doi:10.1029/94PA03039.

McCave, I.N., Thornally, D.J.R., Hall, I.R., 2017. Relation of sortable silt grain-size to deep-sea current speeds: calibration of the "Mud Current Meter". Deep-Sea Res. Part-I, 127, 1-12, doi: 10.1016/j.dsr.2017.07.003.

McManus, J.F., Francois, R. Gherardi, J.M., Keigwin, L.D., Brown-Leger, S., 2004. Collapse and rapid resumption of Atlantic meridional circulation linked to deglacial climate changes. Nature, 428, 834-838, doi:10.1038/nature02494.

Millot, C., 1999. Circulation in the Western Mediterranean Sea. J. Marine Syst. 20, 423442.

Millot, C., 2009. Another description of the Mediterranean Sea Outflow. Prog. Oceanogr. 82(2), 101-124, doi.org/10.1016/j.pocean.2009.04.016.

Moreno, A., Cacho, I., Canals, M., Grimalt, J.O., Sánchez-Goñi, M.F., Shackleton, N.J., Sierro, F.J., 2005. Links between marine and atmospheric processes oscillating at millennial timescale. A multy-proxy study of the last 50,000 yr. from the Alboran Sea (Western Mediterranean Sea). Quaternary Sci. Rev. 24, 1623-1636, doi: 10.1016/j.quascirev.2004.06.018.

Mougenot, D., Vanney, J.-R., 1982. Les rides de contourites Plio-Quaternaires de la pente continentale Sud-Portugaise (The Plio-Quaternary sedimentary drifts of the South Portuguese continental slope). Bull. Inst. Geol. Bass. Aquitaine 31, 131-139.

Mulder, T., Voisset, M., Lecroart, P., Le Drezen, E., Gonthier, E., Hanquiez, V., Faugères, J.C., Habgood, E., Hernandez- Molina, F.J., Estrada, F., Llave, E., Poirier, D., Gorini, C., Fuchey, Y., Volker, A., Freitas, P., Lobo Sanchez, F., Fernandez, L.M., Morel, J., 2003. The Gulf of Cadiz: an unstable giant contouritic levee. Geo-Mar. Lett. 23 (1), 7-18, doi:10.1007/s00367-003-0119-0.

Nadeau, M.-J., Grootes, P.M., Schleicher, M., Hasselberg, P., Rieck, A., Bitterling, M., 1998. Sample throughput and data quality at the Leibniz-Labor AMS Facility. Radiocarbon 40, 239-245.

Naughton, F., Sánchez-Goñi, M.F., Kageyama, M., Bard, E., Duprat, J., Cortijo, E., Desprat, S., Malaizé, B., Joly, C., Rostek, F., Turon, J.L., 2009. Wet to dry climatic trend in northwestern Iberia within Heinrich events. Earth Planet. Sci. Lett. 284 (3-4), 329-342, doi:10.1016/j.eps1.2009.05.001.

Nelson, C.H., Baraza, J., Maldonado, A., 1993. Mediterranean undercurrent Sandy contourites, Gulf of Cadiz, Spain. Sediment. Geol.82, 103-131, doi:10.1016/0037-0738(93)90116-M.

Oppo, D.W., McManus, J.F., Cullen, J.L., 2003. Deepwater variability in the Holocene epoch. Nature 422, 277-278, doi:10.1038/422277b. 
Özgökmen, T.M., Chassignet, E.P., Rooth, C.G.H., 2001. On the Connection between the Mediterranean Outflow and the Azores Current. J. Phys. Oceanogr.31, 461-480, doi:10.1175/1520-0485(2001)031<0461:OTCBTM>2.0.CO;2.

Pelegrí, J.L., Arístegui, J., Cana, L., González-Dávila, M., Hernández-Guerra, A., HernándezLeón, S., Marrero-Díaz, A., Montero, M.F., Sangrá, P., Santana-Casiano, M., 2005 a. Coupling between the open ocean and the coastal upwelling region off northwest Africa: water recirculation and offshore pumping of organic matter. J. Marine Syst. 54 (1-4), 3-37, doi:10.1016/j.jmarsys.2004.07.003.

Pelegrí, J.L., Marrero-Diaz, A., Ratsimandresy, A., Antoranz, A., Cisneros-Aguirre, J., Gordo, C., Grisolía, D., Hernández-Guerra, A., Láiz, I., Martínez, A., Parrilla, G., PérezRodríguez, P., Rodríguez-Santana, A., Sangrà, P., 2005b. Hydrographic cruises off northwest Africa: the Canary Current and the Cape Ghir region. J. Marine Syst. 54 (1-4), 39-63, doi:10.1016/j.jmarsys.2004.07.001.

Penaud, A., Eynaud, F., Voelker, A., Marret, F., Turon, J.L., Rossignol, L., Blamart, D., Mulder, T., 2011. Hydrological processes affecting the subtropical NE Atlantic (34-38 N) over the last $30 \mathrm{ka}$ : evidence from phyto- and zooplankton assemblages. Biogeosciences Discussions 8, 2281-2327, doi:10.5194/bgd-8-2281-2011.

Pflaumann, U., Duprat, J., Pujol, C., Labeyrie, L.D., 1996. SIMMAX: A modern analog technique to deduce Atlantic sea surface temperatures from planktonic foraminifera in deep-sea sediments, Paleoceanography 11, 15-35, doi:10.1029/95PA01743.

Pflaumann, U., Sarnthein, M., Chapman, M., deAbreu, L., Funnell, B., Huels, M., Kiefer, T., Maslin, M., Schulz, H., Swallow, J., van Kreveld, S., Vautravers, M., Vogelsang, E., Weinelt, M., 2003. Glacial North Atlantic: Sea-surface conditions reconstructed by GLAMAP 2000, Paleoceanography 18 (3), 1065. doi:10.1029/2002PA000774.

Quentel, E., Carton, X., Gutscher, M.A., 2011. Structure and Temporal Variability of Mediterranean Water in Hydrological and Marine Seismic Data South of Portimão Canyon (Gulf of Cadiz), from 1999 to 2002. International Journal of Geosciences 2, 185-194, doi:10.4236/ijg.2011.23020

Rebesco, M., Camerlenghi, A., Van Loon, A.J. 2008. Contourite research: a field in full development, 3-10. In Contourites. Rebesco, M., Camerlenghi, A. (Eds), Elsevier, 770 pp.

Rebesco, M., Hernández-Molina, F.J., Van Rooij, D., Wåhlin, A., 2014. Contourites and associated sediments controlled by deep-water circulation processes: State-of-the-art and future considerations. Mar. Geol. 352, 111-154, doi:10.1016/j.margeo.2014.03.011.

Reguera, M.I., 2001. Paleoceanografía y estratigrafía de alta resolución en el Golfo de Cádiz en los últimos 40.000 años mediante el estudio de foraminíferos planctónicos. Master Thesis, University of Salamanca (Spain), 188 pp.

Reguera, M.I., 2004. Respuesta del Mediterráneo Occidental a los cambios climáticos ocurridos durante el último ciclo glacial: estudio de las asociaciones de foraminíferos. Ph.D. Thesis, University of Salamanca (Spain), $231 \mathrm{pp}$.

Reimer, P.J., Baillie, M.G.L., Bard, E., Bayliss, A., Beck, J.W., Blackwell, P.G.,Bronk Ramsey, C., Buck, C.E., Burr, G.S., Edwards, R.L., Friedrich, M., Grootes, P.M., Guilderson, T.P., Hajdas, I., Heaton, T.J., Hogg, A.G., Hughen, K.A., Kaiser, K.F., Kromer, B., McCormac, G., Manning, S.W., Reimer, R.W., Richards, D.A., Southon, J.R., Talamo, S., Turney, C.S.M., van der Plicht, J., Weyhenmeyer, C.E., 2009. INTCAL09 and MARINE09 radiocarbon age calibration curves, $0-50,000$ years cal BP. Radiocarbon 51 (4), 11111150, doi:10.1017/S0033822200034202.

Richardson, P.L., Bower, A.S., Zenk, W., 2000. A census of meddies tracked by floats. Prog. Oceanogr. 45, 209-250.

Rodrigo-Gámiz, M., Martínez-Ruiz, F., Jiménez-Espejo, F.J., Gallego-Torres, D., NietoMoreno, V., Romero, O., Ariztegui, D., 2011. Impact of climate variability in the western Mediterranean during the last 20,000 years: Oceanic and atmospheric responses, Quaternary Sci. Rev. 30 (15-16), 2018-2034, doi:10.1016/j.quascirev.2011.05.011.

Rohling, E.J., Bryden, H.L., 1994. Estimating past changes in the eastern Mediterranean fresh water budget, using reconstructions of sea level and hydrography, Proc. K. Ned. Akad. Van Wetenschappen, Ser. B, 97 (2), 201-217. 
Rogerson, M.,Cacho, I., Jimenez-Espejo, F., Reguera, M.I., Sierro, F.J., Martinez-Ruiz, F., Frigola, J., Canals, M., 2008. A dynamic explanation for the origin of the western Mediterranean organic rich layers, Geochem. Geophy. Geosy. 9, doi: 10.1029/2007GC002931

Rogerson, M., Rohling, E.J., Weaver, P.E.E., 2006. Promotion of meridional overturning by Mediterranean-derived salt during the last deglaciation, Paleoceanography 21, PA4101, doi:10.1029/2006PA001306.

Rogerson, M., Colmenero-Hidalgo, E., Levine, R.C., Rohling, E.J., Voelker, A.H.L., Bigg, G.R., Schönfeld, J., Cacho, I., Sierro, F.J., Lowemark, L., Reguera, M.I., deAbreu, L., Garrick, K., 2010. Enhanced Mediterranean-Atlantic exchange during Atlantic freshening phases. Geochem. Geophy. Geosy. 11 (8), doi: 10.1029/2009GC002931.

Rogerson, M., Rohling, E.J., Weaver, P.P.E., Murray, J.W., 2004. The Azores Front since the Last Glacial Maximum, Earth Planet. Sci. Lett. 222, 779-789.

Rogerson, M., Schönfeld, J., Leng, M.J., 2011. Qualitative and quantitative approaches in palaeohydrography: A case study from core-top parameters in the Gulf of Cadiz. Mar. Geol. 280, 150-167, doi:10.1016/j.margeo.2010.12.008.

Rogerson, M., Rohling, E.J., Bigg, G.R., Ramirez, J., 2012. Paleoceanography of the AtlanticMediterranean exchange: Overview and first quantitative assessment of climatic forcing. Rev. Geophys. 50, RG2003. doi:10.1029/2011RG000376.

Salgueiro, E., Naughton, F., Voelker, A.H.L., de Abreu, L., Alberto, A., Rossignol, L., Duprat, J., Magalhaes, V.H., Vaqueiro, S., Turon, J.L., Abrantes, F., 2014. Past circulation along the western Iberian margin: a time slice vision from the Last Glacial to the Holocene. Quaternary Sci. Rev. 106, 316-329, doi:10.1016/j.quascirev.2014.09.001

Sarnthein, M., Winn, K., Jung, S.J.A., Duplessy, J.-C., Labeyrie, L., Erlenkeuser, H., Ganssen, G., 1994. Changes in east Atlantic deepwater circulation over the last 30,000 years: eight time slice reconstructions. Paleoceanography 9 (2), 209-267, doi:10.1029/93PA03301.

Schönfeld, J., Zahn, R., 2000. Late glacial to Holocene history of the Mediterranean Outflow Water. Evidence from benthic foraminiferal assemblages and stable isotopes at the Portuguese margin. Palaeogeogr. Palaeoclimatol. Palaeoecol.159 (1-3), 85-111, doi:10.1016/S0031-0182(00)00035-3.

Serra, N., Ámbar, I., Boutov, D., 2010. Surface expression of Mediterranean Water dipoles and their contribution to the shelf/slope - open ocean exchange: Ocean Sci. 6, 191-209, doi:10.5194/os-6-191-2010.

Sierro, F.J., Flores, J.A., Baraza, J., 1999. Late glacial to recent paleoenvironmental changes in the Gulf of Cadiz and formation of sandy contourite layers. Mar. Geol. 155, 157-172, doi:10.1016/S0025-3227(98)00145-5.

Sierro, F.J., Hodell, D.A., Curtis, J.H., Flores, J.A., Reguera, I., Colmenero-Hidalgo, E., Bárcena, M.A., Grimalt, J.O., Cacho, I., Frigola, J., Canals, M., 2005. Impact of iceberg melting on Mediterranean thermohaline circulation during Heinrich events. Paleoceanography 20 (2), 13 pp., PA2019, doi:10.1029/2004PA001051.

Stanford, J.D., Rohling, E., Hunter, S.E., Roberts, A.P., Rasmussen, S.O., Bard, E., McManus, J., Fairbanks, R.G., 2006. Timing of meltwater pulse 1a and climate responses to meltwater injections. Paleoceanography, 21, PA4103, doi:10.1029/2006PA001340.

Stow, D.A.V., 1985. Deep-sea clastics: Where are we and where are we going? In: Benchley, P.J. and Williams, B.P.J. (Eds.), Sedimentology: Recent Developments and Applied Aspects. Geological Society of London Special Publications 17, 67-93.

Stow, D.A.V., Faugères, J.-C., Gonthier, E., 1986. Facies distribution and textural variation in Faro Drift contourites: velocity fluctuation and drift growth. Marine Geology, 72, 71-100.

Stow, D.A.V., Lovell, J.P.B., 1979. Contourites: their recognition in modern and ancient sediments. Earth-Sci. Rev. 14, 251-291.

Stow, D.A.V., Pudsey, C.J., Howe, J.A., Faugères, J.C., Viana, A.R., 2002. Deep-water Contourite Systems: Modern Drifts and Ancient Series, Seismic and Sedimentary Characteristics, Memoirs, vol. 22, Geological Society of London, London, 464 pp. 
Stow, D.A.V., Faugères, J.C., 2008. Contourite facies and the facies model, In: M. Rebesco, and A. Camerlenghi (Eds.), Developments in Sedimentology, 60, Elsevier, pp. 223-256, doi:10.1016/S0070-4571(08)10013-9.

Stow, D.A.V., Hernández-Molina, F.J., Llave, E., Bruno, M., García, M., Díaz del Rio, V., Somoza, L., Brackenridge, R.E., 2013. The Cadiz Contourite Channel: Sandy contourites, bedforms and dynamic current interaction. Mar. Geol. 343, 99-114, doi:10.1016/j.margeo.2013.06.013.

Stuiver, M., Reimer, P.J., 1993. Extended ${ }^{14} \mathrm{C}$ data base and revised CALIB $3.0{ }^{14} \mathrm{C}$ age calibration program. Radiocarbon 35 (1), 215-230, doi:10.1017/S0033822200013904.

UTM (Unidad Tecnología Marina). Informe Técnico Campaña Oceanográfica HE-129 MVSEIS, BIO HESPERIDES, 16 Mayo a 1 Junio de 2008, CMIMA-CSIC, (IP científico L.Somoza, IGME), España, 73 pp.

Telford, R.J., Andersson, C., Birks, H.J.B., Juggins, S., 2004. Biases in the estimation of transfer function prediction errors. Paleoceanography 19, PA4014, doi: 1029/ 2004PA001072.

Toucanne, S., Mulder, T., Schönfeld, J., Hanquiez, V., Gonthier, E., Duprat, J., Cremer, M., Zaragosi, S., 2007. Contourites of the Gulf of Cadiz: a high-resolution record of the paleocirculation of the Mediterranean outflow water during the last 50,000 years, Palaeogeogr. Palaeoclimatol. Palaeoecol.246, 354-366, doi:10.1016/j.palaeo.2006.10.007.

Toucanne, S., Jouet, G., Ducassou, E., Bassetti, M.-A., Dennielou, B., Angue Minto'o, C.M., Lahmi, M., Touyet, N., Charlier, K., Lericolais, G., Mulder, T., 2012. A 130,000-year record of Levantine Intermediate Water flow variability in the Corsica Trough, western Mediterranean Sea, Quaternary Sci. Rev. 33 (55-73), doi: 10.1016/j.quascirev.2011.11.020.

Treguier, A.M., Deshayes, J., Lique, C., Dussin, R., Molines, J.M., 2012. Eddy contributions to the meridional transport of salt in the North Atlantic. J. Geophys. Res.-Oceans 117 (C5), doi:10.1029/2012JC007927.

Vancraeynest, F., 2015. Contourite depositional systems in the El Arraiche area, Moroccan Atlantic margin. Master of Sciences in Geologie, University of Ghent, 55 pp.

Van den Berghe, M., 2015. First quantitative assessment of buried cold-water coral mounds along the Moroccan Atlantic margin, Master of Sciences in Geologie, University of Ghent, $54 \mathrm{pp}$.

Vandorpe, T., Van Rooij, D., de Haas, H., 2014. Stratigraphy and paleoceanography of a topography-controlled contourite drift in the Pen Duick area, southern Gulf of Cadiz. Mar. Geol. 349, 136-151, doi:10.1016/j.margeo.2014.01.007.

Van Rooij, D., Blamart, D., De Mol, L., Mienis, F., Pirlet, H., Wehrmann, L-M., Barbieri, R., Maignien, L., Templer, S.P., de Haas, H., Hebbeln, D., Frank, N., Larmagnat, S., Stadnitskaia, A., Stivaletta, N., van Weering, T., Zhang, Y., Hamoumi, N., Cnudde, V., Duyck, P., Henriet J.-P., The MiCROSYSTEMS MD 169 shipboard party, 2011. Coldwater coral mounds on the Pen Duick Escarpment, Gulf of Cadiz: the MiCROSYSTEMS project approach. Mar. Geol. 282, 102-117, doi:10.1016/j.margeo.2010.08.012.

Van Sebille, E., Baringer, M.O., Johns, W.E., Meinen, C.S., Beal, L.M., de Jong, M.F., van Aken, H.M., 2011. Propagation pathways of classical Labrador Sea water from its source region to 26 N, J. Geophys. Res. 116, C12027, doi:10.1029/2011JC007171.

Van Tornhout, E., 2017. Upper slope of the Northern Moroccan Atlantic margin over the past 1.6 My. Master of Sciences in Geologie, University of Ghent, 54 pp.

Verdiere, A.C., 1992. On the Southward Motion of Mediterranean Salt Lenses, J. Phys. Ocenogr. 22, 413-420.

Vergnaud-Grazzini, C., Caralp, M., Faugerès, J.C., Gonthier, E., Grousset, F., Pujol, C., Saliège, J.F., 1989. Mediterranean Outflow through the Strait of Gibraltar since 1800 years B.P. Oceanol. Acta 12 (4), 305-324.

Vergnaud-Grazzini, C., Pierre, C., 1991. High fertility in the Alboran Sea since the Last Glacial Maximum. Paleoceanography 6 (4), 519-536, doi:10.1029/91PA00501. 
Voelker, A.H.L., Lebreiro, S.M., Schönfeld, J., Cacho, I., Erlenkeuser, H., Abrantes, F, 2006. Mediterranean outflow strengthening during northern hemisphere coolings: A salt source for the glacial Atlantic? Earth Planet. Sci. Lett. 245, 39-55, doi:10.1016/j.epsl.2006.03.014.

Volkov, D.L., Fu, L.-L., 2010. On the reasons for the formation and variability of the Azores Current. J. Phys. Oceanogr.40, 2197-2220, doi:10.1175/2010JPO4326.1.

Wanner, H., Solomina, O., Grosjean, M., Ritz, S.P., Jetel, M., 2011. Structure and origin of Holocene cold events, Quaternary Sci. Rev. 30 (21-22), 3109-3123, doi: 10.1016/j.quascirev.2011.07.010.

Weltje, G. J., Tjallingii, R., 2008. Calibration of XRF core scanners for quantitative geochemical logging of sediment cores: Theory and application, Earth Planet. Sci. Lett. 274, 423-438, doi:10.1016/j.eps1.2008.07.054.

Zahn, R., Sarnthein, M., Erlenkeuser, H., 1987. Benthic isotope evidence for changes or the Mediterranean outflow during the late Quaternary. Paleoceanography 2 (6), 543-559, doi:10.1029/PA002i006p00543.

Zenk, W., 1975. On the origin of the intermediate double-maxima in T/S profiles from the North Atlantic. "Meteor" Forsch.-Ergebnisse, 16 (31-43). 


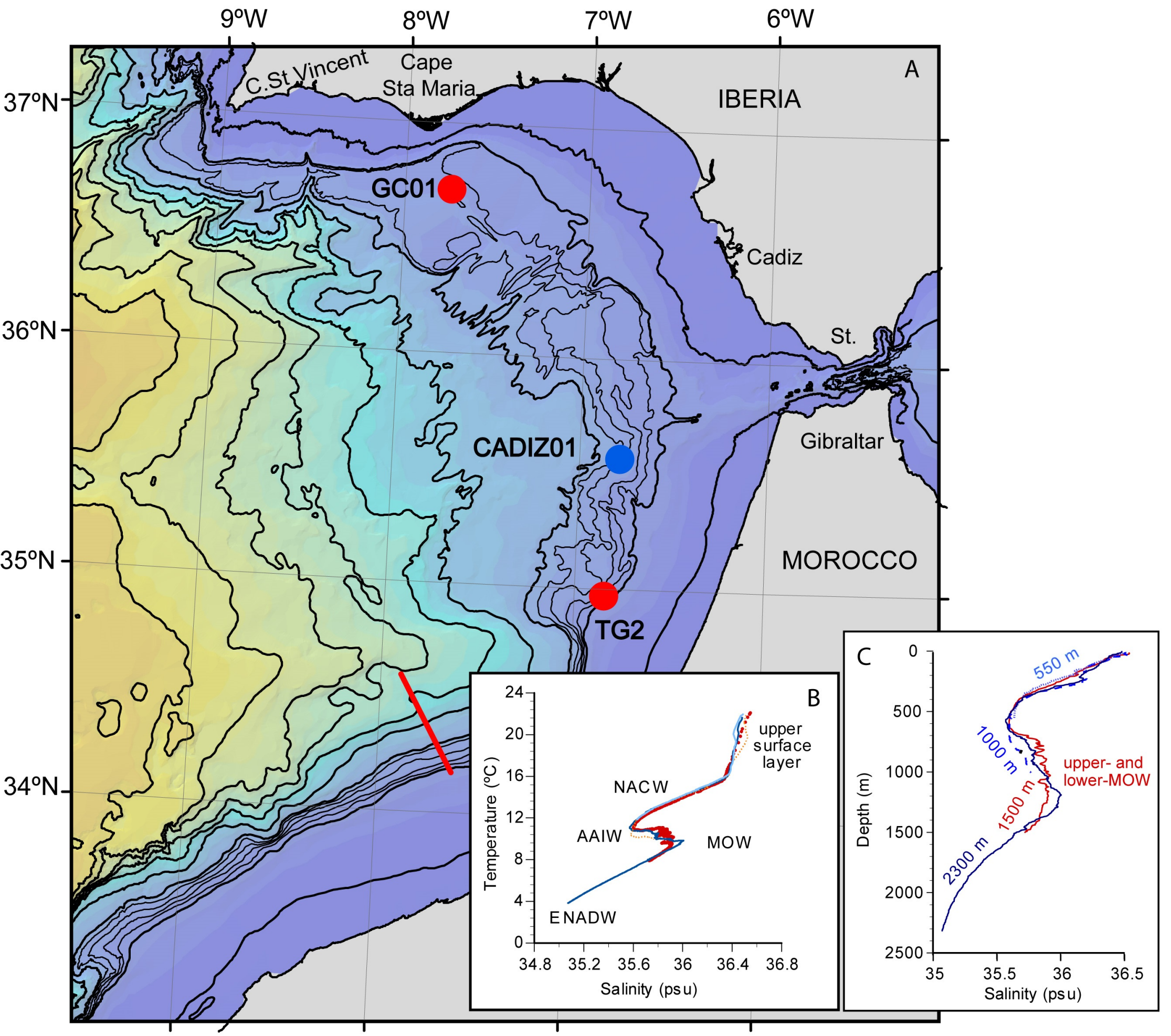

Fig.1 Lebreiro et al. 

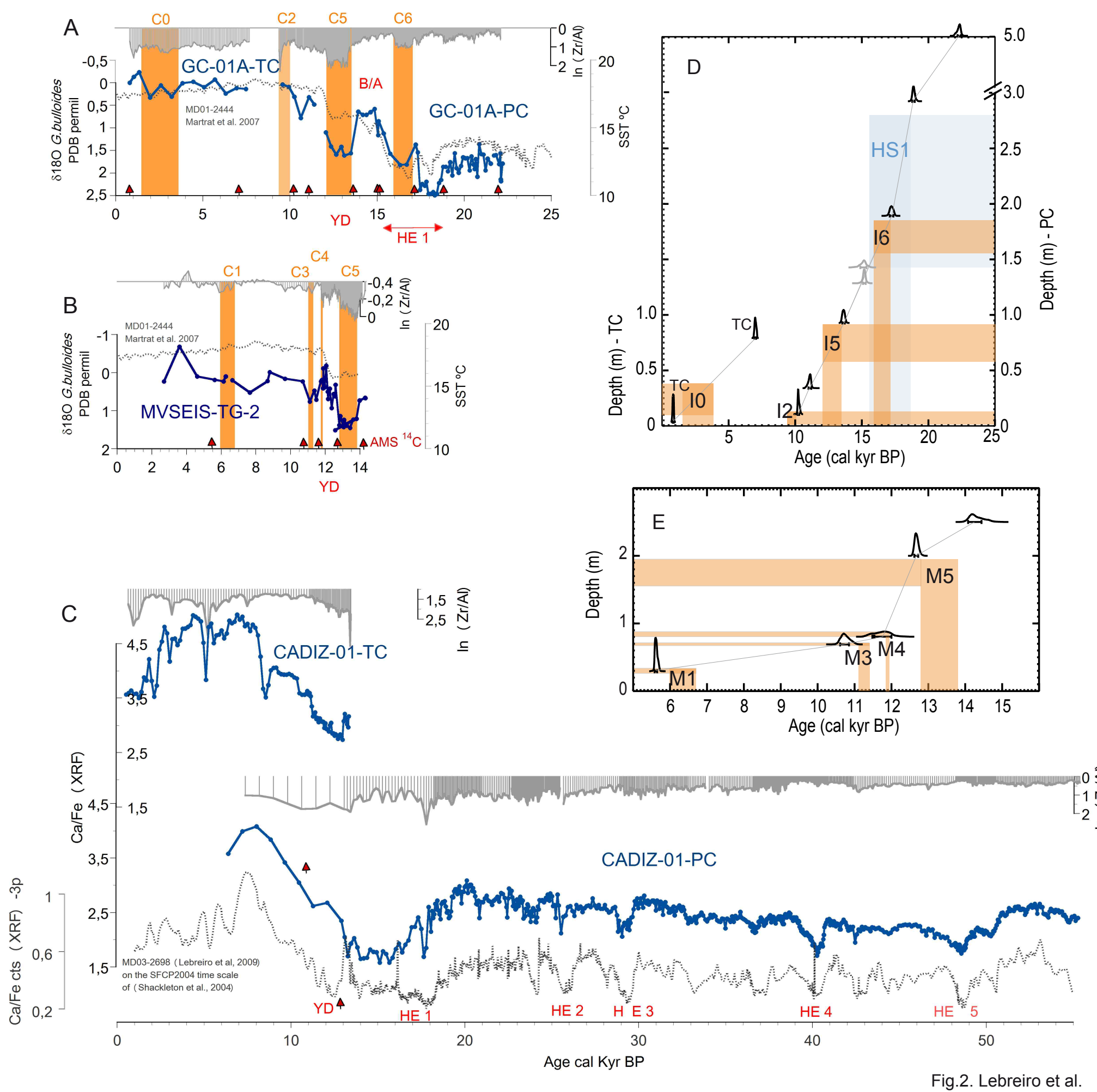


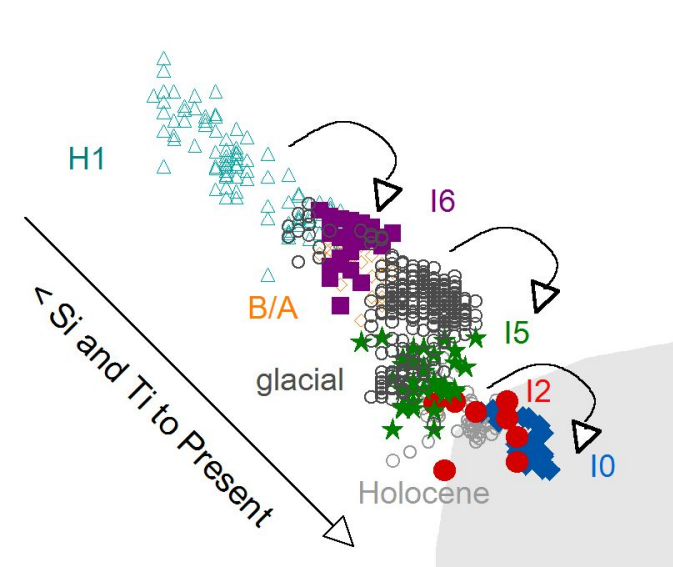

$\mathrm{Ti} / \mathrm{Ca} \quad 0,06$ $0,04 \quad 0,02$ $\mathrm{Sr} / \mathrm{Ca}{ }^{0,04}$

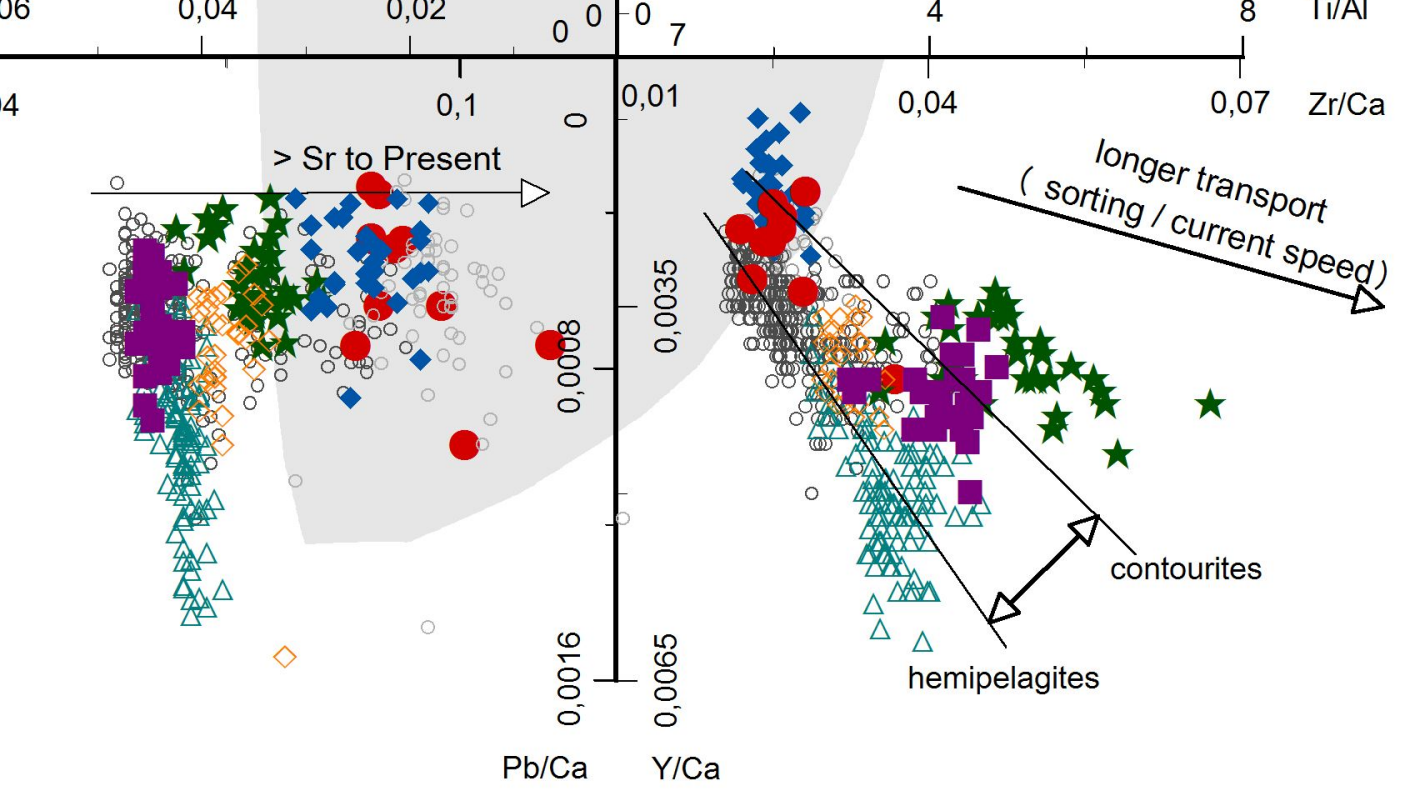

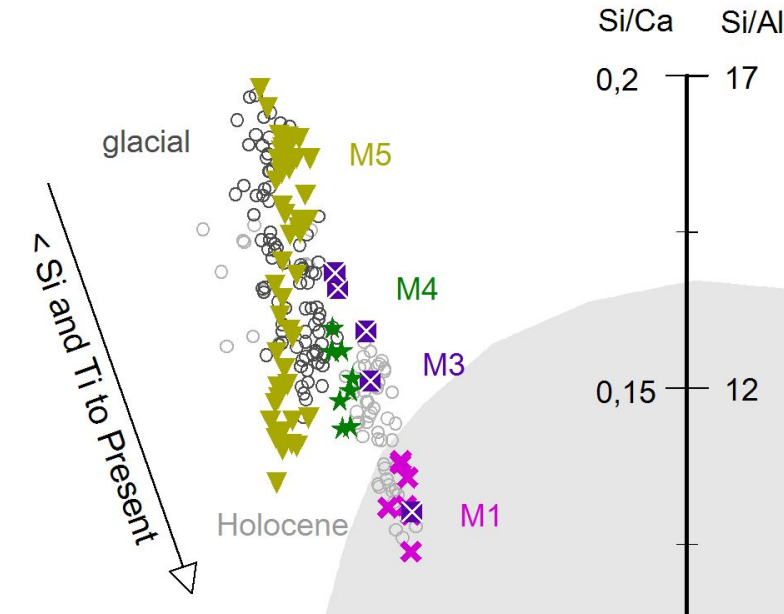

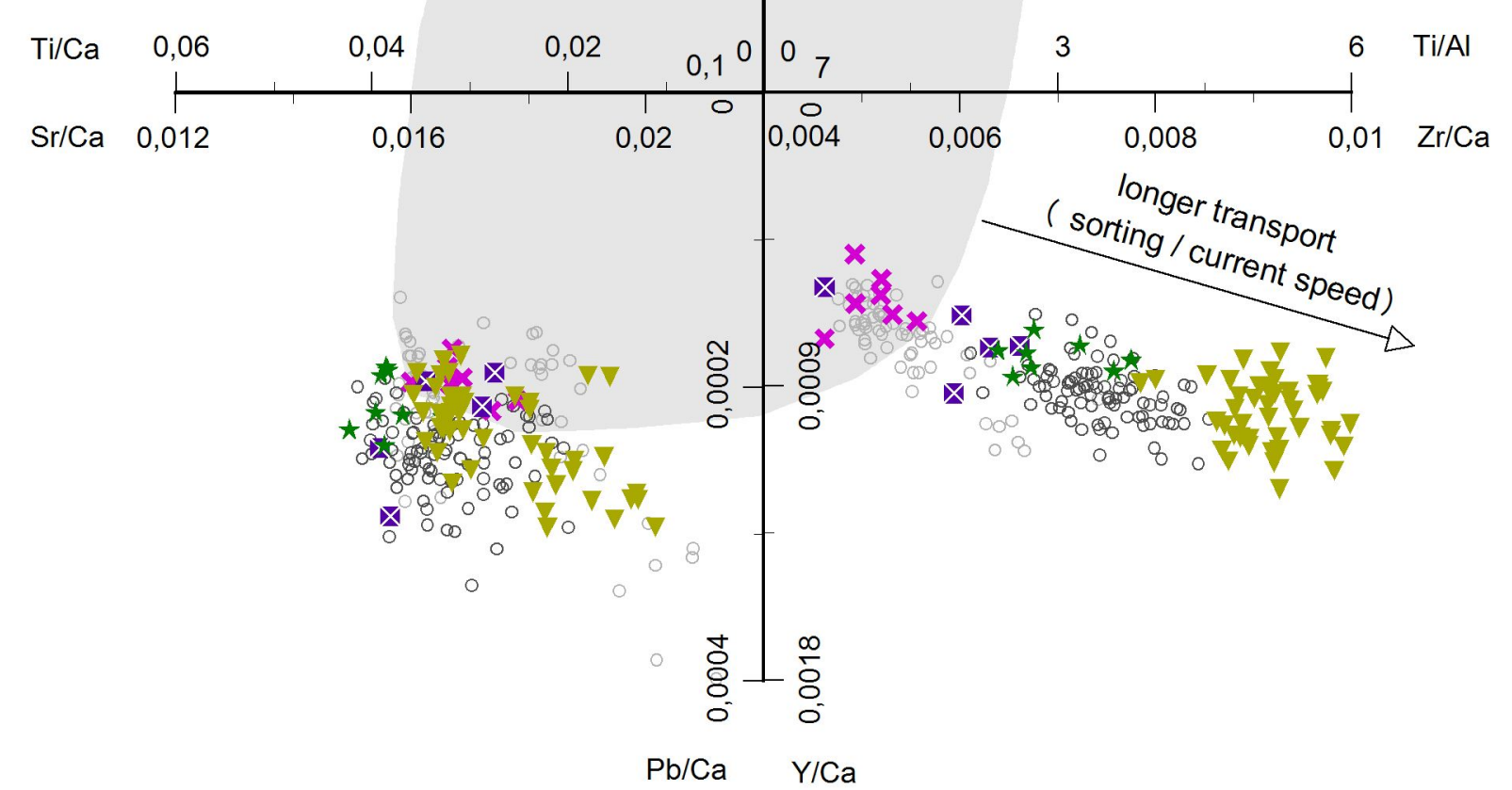

Fig3. Lebreiro et al. 


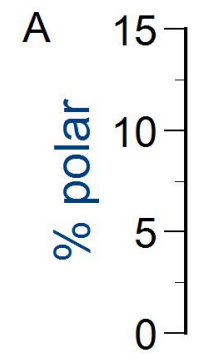

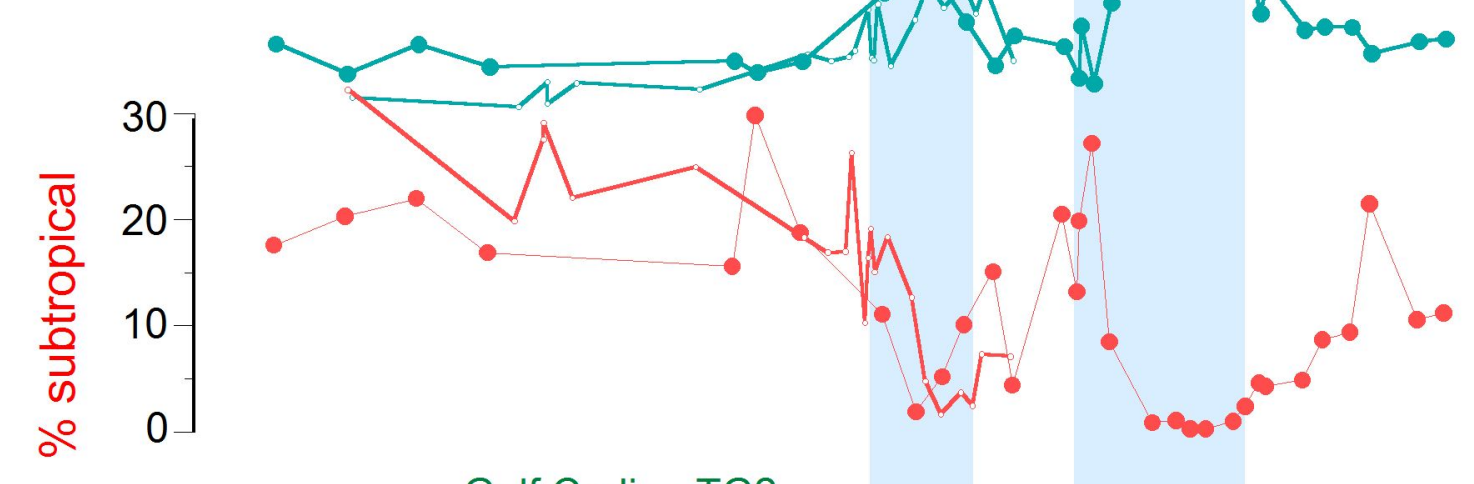

B

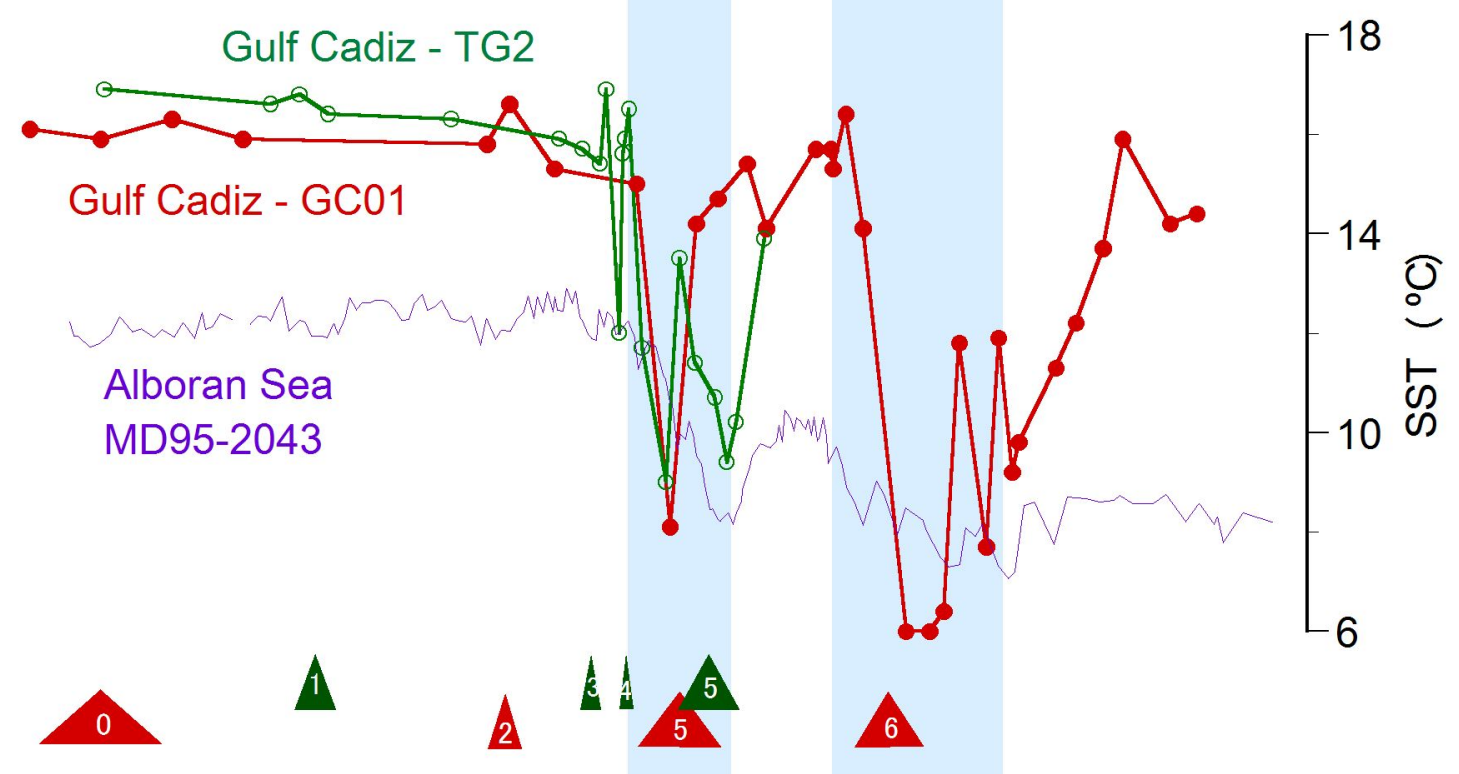

C

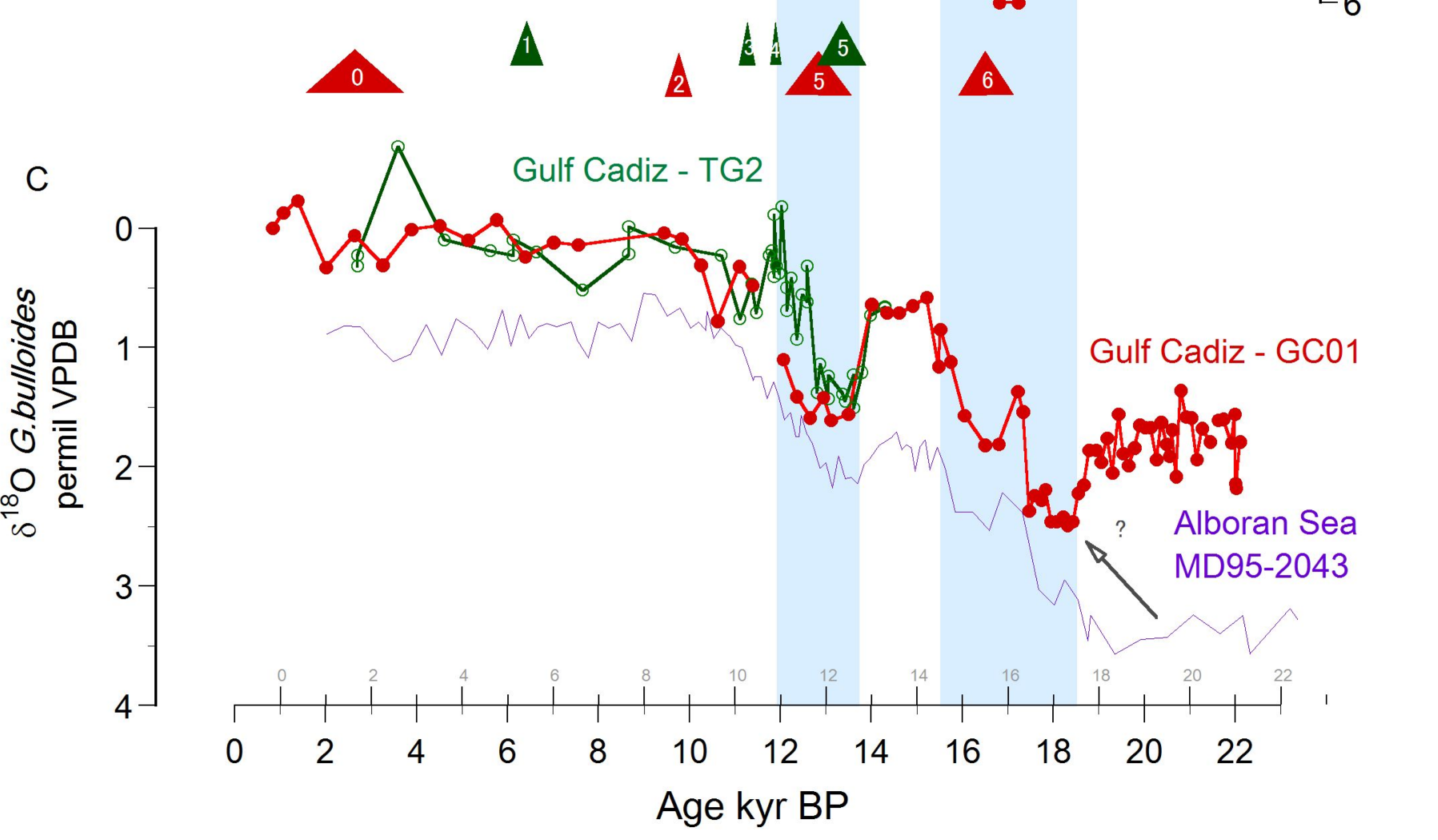

Fig.4. Lebreiro et al. 

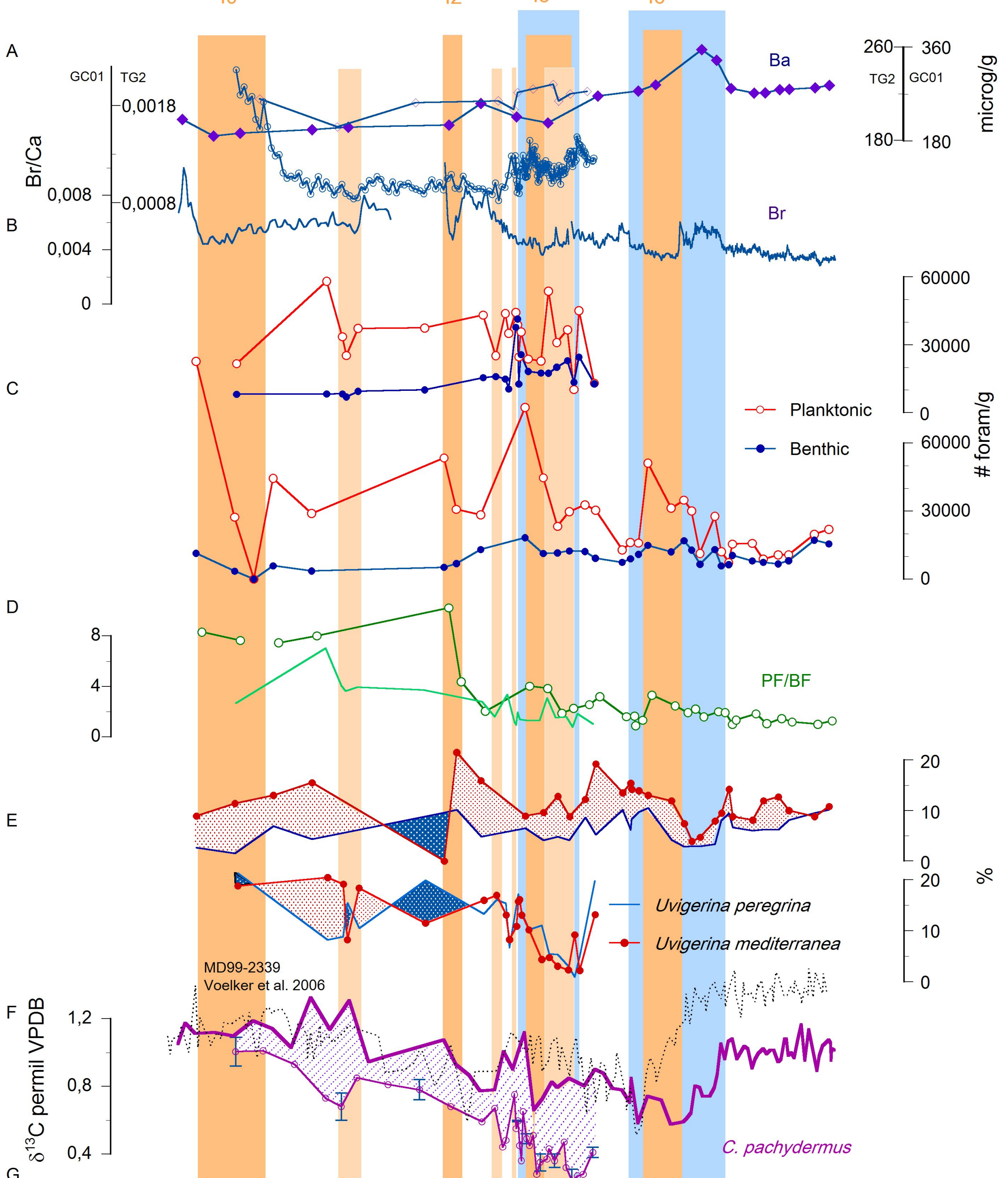

G
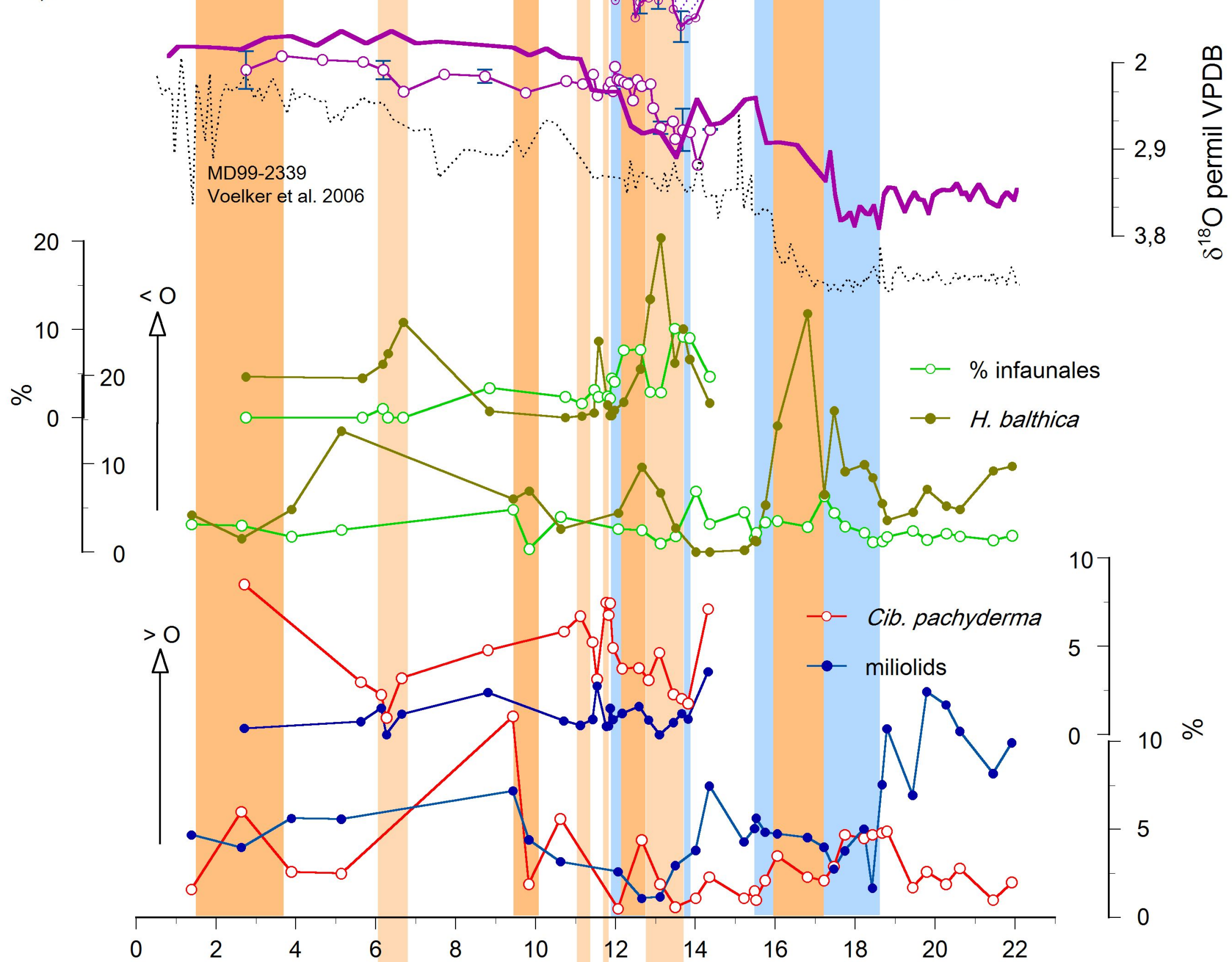

Age ky BP 

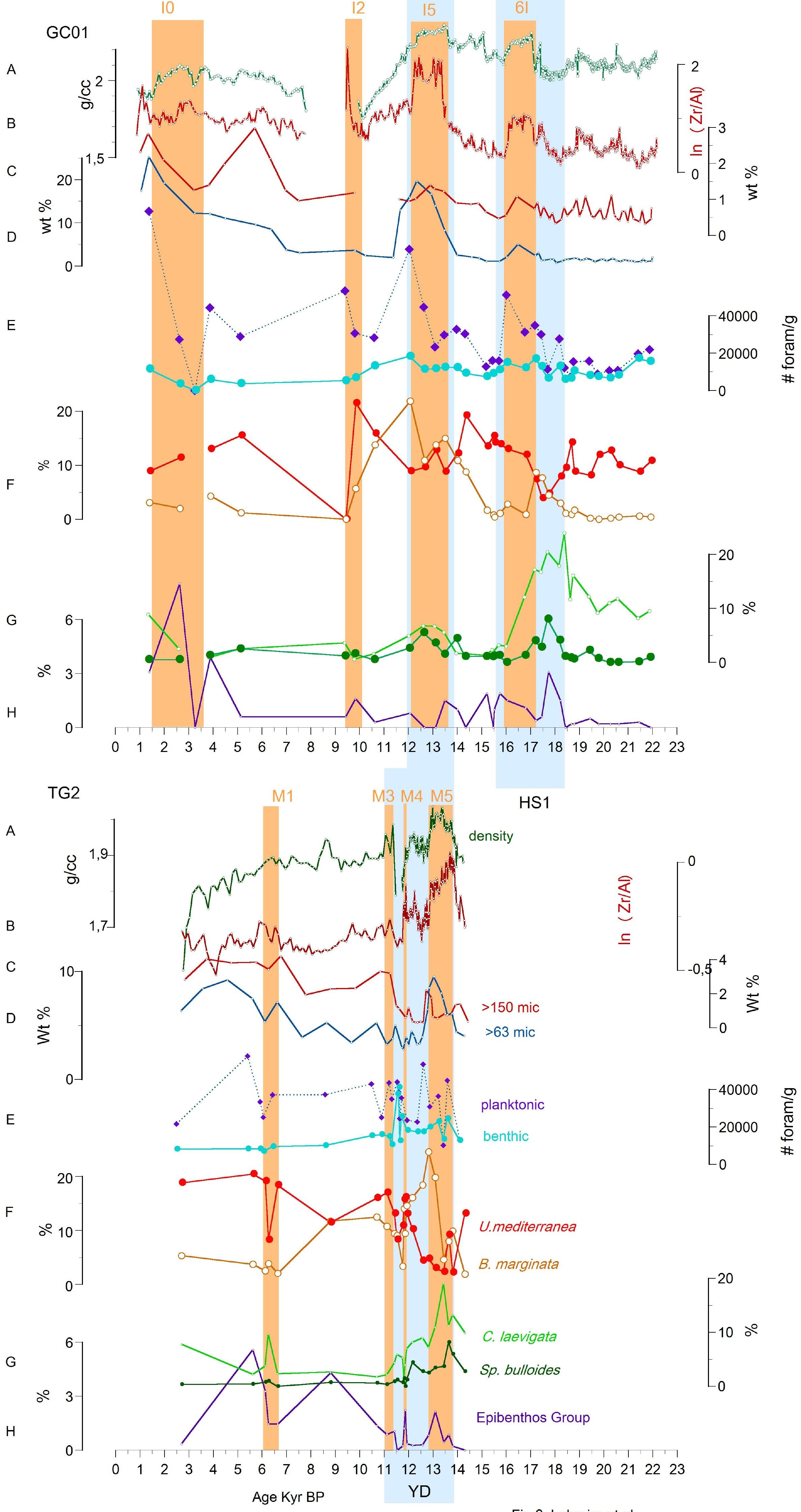

Fig 6. Lebreiro et al. 


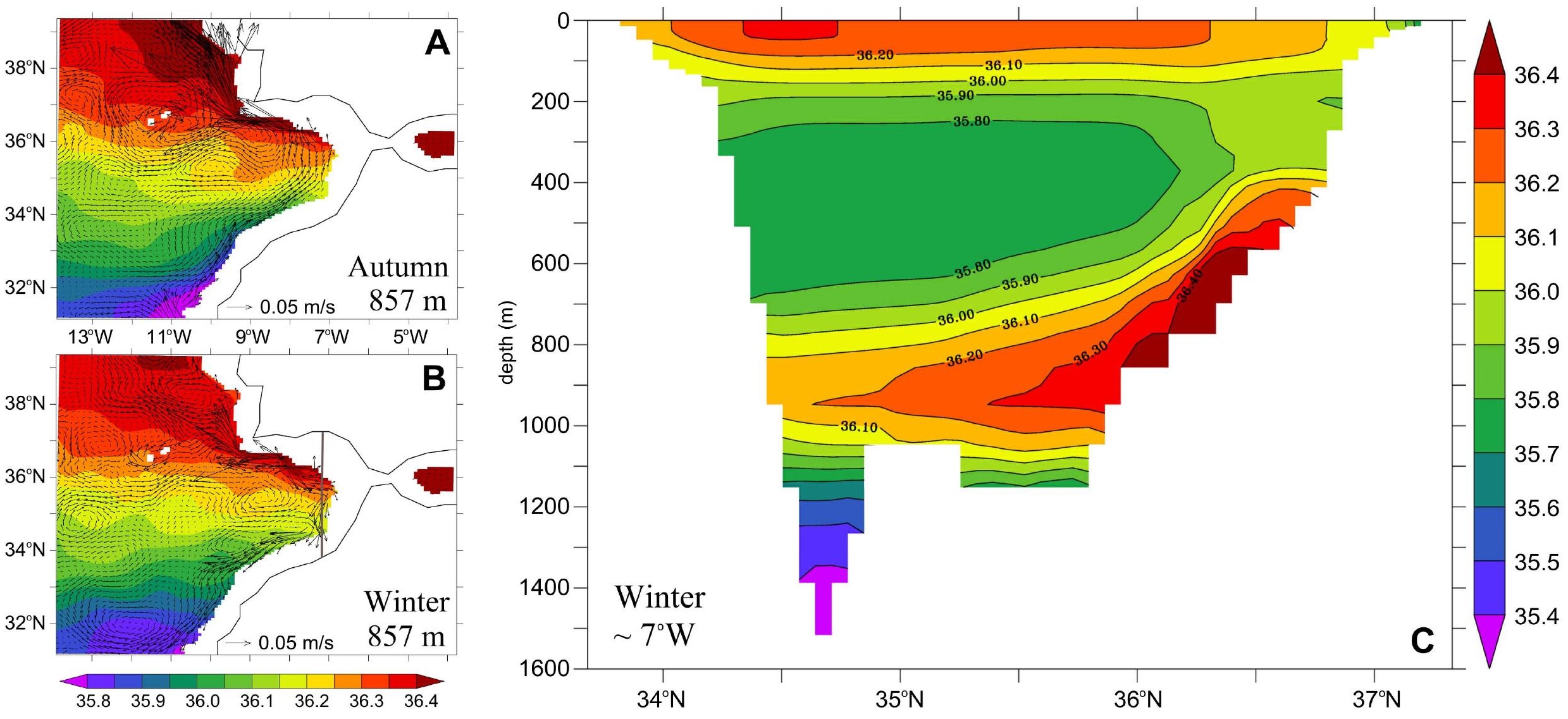



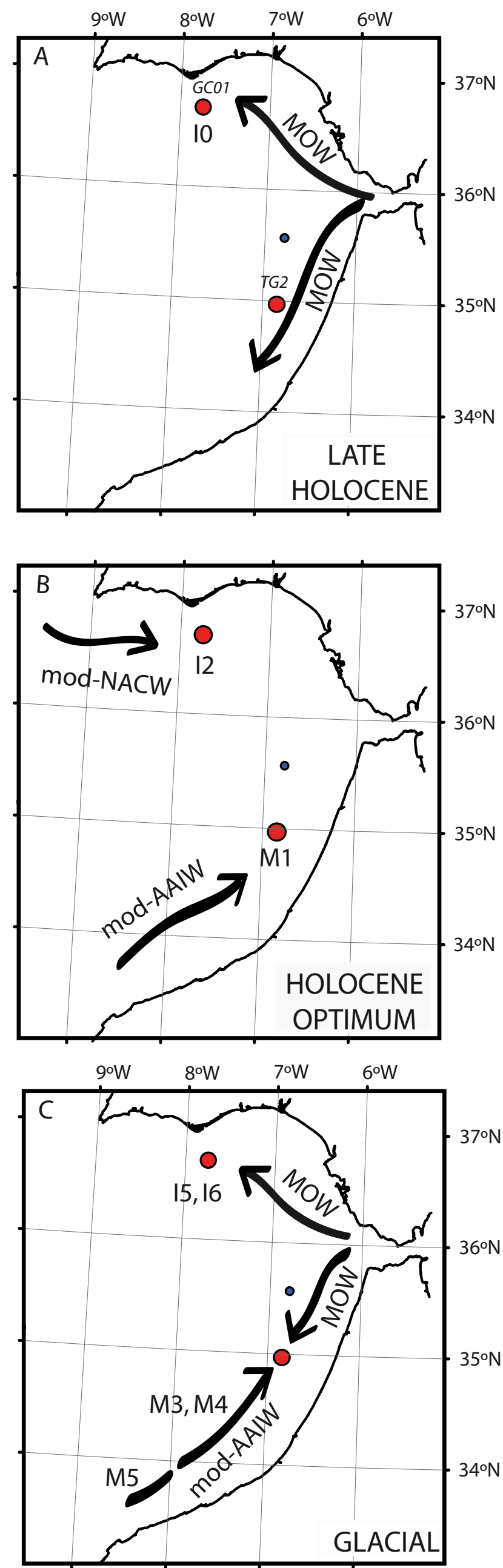

Fig.8. Lebreiro et al. 


\begin{tabular}{|c|c|c|c|c|c|c|c|c|c|c|}
\hline Sample reference & $\begin{array}{l}\text { Depth in section }(\mathrm{cm}) \\
\text { Depth in core }(\mathrm{cm})\end{array}$ & $\begin{array}{l}\text { Laboratory } \\
\text { Reference* }\end{array}$ & Material & Weight (mg) & $\begin{array}{l}\text { Amount of C } \\
\text { analysed (mg) }\end{array}$ & $\begin{array}{c}\text { Corrected } \\
\text { pMC† }\end{array}$ & $\delta^{13} \mathrm{C}(\%) \pm$ error & $\begin{array}{c}\text { Conventional Age yr } \\
\text { BP }\end{array}$ & $\begin{array}{c}\text { Reservoir } \\
\text { corrected }{ }^{14} \mathrm{C} \\
\text { Age yr BP } \\
\end{array}$ & $\begin{array}{c}68.3 \%(1 \sigma) \\
\text { Age ranges } \\
\text { (calendar yr BP) }\end{array}$ \\
\hline TG2-S1 & $24-25$ & KIA46898 & $\begin{array}{l}\text { bulloides, ruber, inflata, truncatulinoides, } \\
\text { universa }>250 \mu \mathrm{m}\end{array}$ & 11,1 & 1.0 & $51.94 \pm 0.24$ & $0.01 \pm 0.28$ & $5265 \pm 35$ & 5623 & $5581-5651$ \\
\hline TG2-S1 & $64-65$ & KIA46899 & $\begin{array}{c}\text { bulloides, ruber, inflata, truncatulinoides, } \\
\text { universa }>250 \mu \mathrm{m}\end{array}$ & 10,2 & 0.9 & $29.50 \pm 0.31$ & $1.03 \pm 0.11$ & $9810 \pm 80$ & 10702 & $10559-10804$ \\
\hline TG2-S2 & $\begin{array}{c}4-5 \\
74-75\end{array}$ & KIA46900 & $\begin{array}{l}\text { bulloides, ruber, inflata, truncatulinoides > } \\
\qquad 150 \mu \mathrm{m}\end{array}$ & 7,8 & 0.7 & $26.92 \pm 0.35$ & $-2.65 \pm 0.19$ & $10540+110 /-100$ & 11734 & $11412-11515$ \\
\hline TG2-S2 & $\begin{array}{c}71-74 \\
141-144\end{array}$ & KIA 44972 & $\begin{array}{l}\text { bulloides, ruber, inflata, falconensis, } \\
\text { truncatulinoides, universa }>150 \mu \mathrm{m}\end{array}$ & 6,7 & 0.7 & $24.84 \pm 0.18$ & $-1.67 \pm 0.22$ & $11185 \pm 55$ & 12665 & $12599-12712$ \\
\hline TG2-S2 & $\begin{array}{l}140-141 \\
210-211\end{array}$ & KIA 49744 & $\begin{array}{c}\text { inflata, bulloides, ruber, truncatulinoides, } \\
\text { universa }>150 \mu \mathrm{m}\end{array}$ & 5,95 & 0,4 & $20.57 \pm 0.21$ & $-0.39 \pm 0.25$ & $12700 \pm 80$ & 14265 & $14018-14262$ \\
\hline GC01A-TC & $1-2$ & KIA46901 & $\begin{array}{c}\text { bulloides, ruber, inflata, truncatulinoides, } \\
\text { universa }>250 \mu \mathrm{m}\end{array}$ & 10,4 & 1.0 & $85.17 \pm 0.30$ & $0.47 \pm 0.37$ & $1290 \pm 30$ & 836 & 793-883 \\
\hline GC01A-TC & $80-81$ & KIA 49736 & inflata, ruber $>250 \mu \mathrm{m}$ & 9,3 & 0.9 & $44.53 \pm 0.23$ & $0.17 \pm 0.19$ & $6500 \pm 40$ & 7010 & $6940-7075$ \\
\hline GC01A-S1 & $17-18$ & KIA 49737 & $\begin{array}{l}\text { ruber, inflata, truncatulinoides, universa, } \\
\text { bulloides }>250 \mu \mathrm{m}\end{array}$ & 9,67 & 0.6 & $31.01 \pm 0.21$ & $0.77 \pm 0.23$ & $9405 \pm 55$ & 10253 & 10181-10312 \\
\hline GC01A-S1 & $33-34$ & KIA46902 & $\begin{array}{l}\text { bulloides, ruber, inflata, truncatulinoides, } \\
\text { universa }>250 \mu \mathrm{m}\end{array}$ & 10,4 & 0.8 & $28.43 \pm 0.33$ & $0.08 \pm 0.08$ & $10100 \pm 90$ & 11093 & $10994-10970$ \\
\hline GC01A-S1 & 93-94 & KIA 49738 & $\begin{array}{l}\text { inflata, bulloides, truncatulinoides, } \\
\text { universa, ruber }>150 \mu \mathrm{m}\end{array}$ & 10,18 & 1.0 & $21.94 \pm 0.18$ & $-0.74 \pm 0.31$ & $12180 \pm 70$ & 13621 & $13510-13557$ \\
\hline GC01A-S2 & $\begin{array}{c}26-27 \\
127.2-128.2\end{array}$ & KIA 49739 & $\begin{array}{l}\text { inflata, bulloides, ruber, } \\
\text { truncatulinoides, universa }>150 \mu \mathrm{m}\end{array}$ & 10,5 & 0.9 & $19.45 \pm 0.17$ & $-0.85 \pm 0.34$ & $13150 \pm 70$ & 15120 ** & $14915-15250$ \\
\hline GC01A-S2 & $\begin{array}{c}42-43 \\
143.2-144.2\end{array}$ & KIA46903 & $\begin{array}{c}\text { bulloides, ruber, inflata, truncatulinoides, } \\
\text { universa }>150 \mu \mathrm{m}\end{array}$ & 9,3 & 0.9 & $19.52 \pm 0.30$ & $-0.88 \pm 0.14$ & $13130+130-120$ & 15090 ** & $14955-15200$ \\
\hline GC01A-S2 & $\begin{array}{c}87-88 \\
188.2-189.2\end{array}$ & KIA 49740 & bulloides, universa $>250 \mu \mathrm{m}$ & 9,16 & 0.8 & $16.32 \pm 0.16$ & $-2.03 \pm 0.21$ & $14560 \pm 80$ & 17218 & $17040-17408$ \\
\hline GC01A-S3 & $\begin{array}{c}91-92 \\
292.7-293.7\end{array}$ & KIA 49741 & $\begin{array}{l}\text { inflata, universa, ruber, truncatulinoides, } \\
\text { bulloides }>150 \mu \mathrm{m}\end{array}$ & 10,75 & 0.9 & $13.56 \pm 0.16$ & $0.20 \pm 0.21$ & $16050 \pm 90$ & 18792 & $18692-18873$ \\
\hline GC01A-S5 & $\begin{array}{l}99.3-100.3 \\
511.1-512.1\end{array}$ & KIA47835 & $\begin{array}{l}\text { bulloides, ruber, inflata, truncatulinoides, } \\
\text { universa }>150 \mu \mathrm{m}\end{array}$ & 11 & 1.1 & $9.58 \pm 0.13$ & $2.00 \pm 0.30$ & $18840 \pm 110$ & 21992 & $21780-22244$ \\
\hline CADIZ-01-TC & $71-72$ & KIA 49742 & $\begin{array}{c}\text { inflata, ruber, truncatulinoides, bulloides, } \\
\text { universa }>150 \mu \mathrm{m}\end{array}$ & 10,4 & 1.0 & $28.78 \pm 0.19$ & $-0.23 \pm 0.23$ & $10005 \pm 55$ & 10988 & $10907-11116$ \\
\hline CADIZ-01-S1 & $9-10$ & KIA 49743 & $\begin{array}{c}\text { inflata, truncatulinoides, bulloides, ruber, } \\
\text { universa }>150 \mu \mathrm{m}\end{array}$ & 10,33 & 1.0 & $23.98 \pm 0.18$ & $1.83 \pm 0.19$ & $11470 \pm 60$ & 12957 & $12878-13090$ \\
\hline
\end{tabular}

* Leibniz Labor für Altersbestimmung und Isotopenforschung - Kiel, Germany.
** Not used for age model, but interpolation between adjacent ${ }^{14} \mathrm{C}$ ages gives 14913 yrs (for GC01A-S2-26cm) and 15518 yrs (for GC01A-S2-42cm). 
Table 2. Duration and sedimentation rates of contourites in the Iberian (I) and Moroccan margins.

\begin{tabular}{|c|c|c|c|c|c|c|}
\hline & & Depth (cm) & $\begin{array}{c}\text { Age (cal Kyr } \\
\text { BP) }\end{array}$ & $\begin{array}{c}\text { Duration } \\
\text { (kyr) }\end{array}$ & $\begin{array}{l}\text { Sedimentation } \\
\text { rate } \mathrm{cm} / \mathrm{kyr}\end{array}$ & Climatic Event \\
\hline \multirow[t]{2}{*}{ GC01-TC } & 10 & 10 & 1.539 & 2.189 & 12.8 & $2.8 \mathrm{kyr}$ \\
\hline & & 38 & 3.728 & & & \\
\hline \multirow[t]{12}{*}{ GC01-PC } & 12 & 1 & 9.410 & 0.630 & 19.0 & deglaciation \\
\hline & & 13 & 10.040 & & & \\
\hline & 15 & 57 & 12.104 & 1.433 & 23.7 & YD \\
\hline & & 91 & 13.537 & & & \\
\hline & 16 & 155 & 15.971 & 1.134 & 26.5 & HS1 \\
\hline & & 185 & 17.105 & & & \\
\hline & YD & 50 & 11.986 & 1.723 & 26.1 & \\
\hline & & 95 & 13.709 & & & \\
\hline & $B / A$ & 93 & 13.734 & 1.746 & 28.6 & \\
\hline & & 143 & 15.480 & & & \\
\hline & $\mathrm{H} 1$ & 143 & 15.518 & 3.078 & 44.5 & \\
\hline & & 280 & 18.596 & & & \\
\hline \multirow[t]{12}{*}{ TG2 } & M1 & 27 & 6.004 & 0.761 & 7.9 & $6.5 \mathrm{kyr}$ (end $\mathrm{HO}$ )? \\
\hline & & 33 & 6.765 & & & \\
\hline & M3 & 68 & 11.115 & 0.309 & 9.7 & YD \\
\hline & & 71 & 11.424 & & & \\
\hline & M4 & 80 & 11.817 & 0.098 & 71.4 & YD \\
\hline & & 87 & 11.915 & & & \\
\hline & M5 & 155 & 12.860 & 0.997 & 43.1 & YD \\
\hline & & 198 & 13.857 & & & \\
\hline & YD & 68 & 11.115 & 2.742 & 47.4 & \\
\hline & & 198 & 13.857 & & & \\
\hline & $B / A$ & 198 & 13.880 & 0.430 & 51.0 & \\
\hline & & 220 & 14.311 & & & \\
\hline
\end{tabular}

